\title{
Análisis del delito de maltrato animal (art. 337 CP)
}

\author{
Miguel Boiso Cuenca \\ Universidad de Alcalá, España
}

Cita recomendada. BOISO CUENCA, M., Análisis del delito de maltrato animal (art. $337 \mathrm{CP}$ ), dA. Derecho Animal (Forum of Animal Law Studies) 12/1 (2021). - DOI https://doi.org/10.5565/rev/da.519

Agradecimientos. Quiero expresar mi gratitud a la Dra. Raquel Roso Cañadillas, de la Universidad de Alcalá, por haber tutorizado este trabajo.

\section{Resumen}

El objetivo de este trabajo es analizar en profundidad el delito de maltrato animal tipificado en el artículo 337 del Código Penal, analizando todos sus elementos que componen tanto el tipo básico como al agravado, cualificado y atenuado, todo ello desde una posición crítica y analítica. Para ello, se han tenido en cuenta y se han observado las diferentes posiciones doctrinales, la (muchas veces polémica y poco consolidada) jurisprudencia y la normativa europea y estatal. Tras el estudio de estos elementos se ha determinado que dada la redacción actual del delito se plantean bastantes y diferentes cuestiones interpretativas a resolver, las cuales son puestas de manifiesto y resueltas a lo largo de todo este trabajo.

Palabras clave: maltrato animal; causas de justificación; derechos subjetivos; explotación sexual; interpretación; pena.

Abstract - Analysis of the animal abuse crime (art. 337 CP)

The aim of this work is to thoroughly analyse the animal abuse crime set out in article 337 of the Criminal Code, analysing all the elements required as much for the basic as for the aggravated, qualified and mitigated forms, from a critical and analytical perspective. To do so, different doctrinal perspectives, jurisprudence (often controversial and little consolidated) and European and state regulations have been considered and analysed. Following the study of these elements it has been determined that the current composition of the crime presents various different interpretative questions to be resolved, which are brought to light and resolved throughout this work.

Keywords: animal abuse; grounds of justification; subjective rights; sexual exploitation; interpretation; punishment. 


\section{Indice}

1. Introducción

2. Evolución histórica del delito en España

3. Bien jurídico protegido

4. Tipo básico

5. Iter criminis

6. Causas de justificación

7. Pena

8. Tipo agravado

9. Tipo cualificado

10. Tipo atenuado

11. Problemas concursales

12. Referencias

Anexo

Índice jurisprudencial

\section{Introducción}

\section{A mi abuela, donde quiera que me esté viendo estará orgullosa}

La última reforma del Código Penal en 2015 modificó sustancialmente el delito de maltrato animal, añadiendo numerosos elementos que iremos analizando a lo largo de este trabajo, y sobre los cuales existen diferentes opiniones doctrinales, la mayoría de ellas muy contradictorias entre sí.

Por ello, este trabajo trata de ofrecer una interpretación coherente y completa del delito teniendo en cuenta estas posiciones doctrinales, pero tomando partido y aportando soluciones a las diferentes cuestiones planteadas usando ejemplos reales.

Se empezará con un pequeño recorrido a la historia de nuestro país en la legislación relativa a los derechos de los animales, y más concretamente de la evolución del delito estudiado desde que se tipificara como tal en 1995.

Abordaremos diferentes temas, desde la problemática existente en torno a cuál es el bien jurídico protegido de este delito, hasta los problemas concursales más comunes existentes entre el delito de maltrato animal y otros delitos, pasando por todos los problemas derivados principalmente de la pobre redacción del delito.

Uno de los problemas más importantes que se originan por este motivo y que más dividida mantiene a la doctrina, es la conducta típica contemplada en el tipo básico, la cual puede ser una única conducta con dos vertientes o dos conductas independientes una de otra, al cual daremos solución en su correspondiente epígrafe.

Otra de las cuestiones importantes planteadas, que esta vez no deriva de la redacción del artículo, es la de cuáles son las causas de justificación que permiten realizar una conducta, que en principio es típica, pero queda amparada bajo una de estas causas. Para ello nos ayudaremos principalmente la normativa estatal y europea.

Estos y muchos otros asuntos se resolverán a lo largo de todo el trabajo, a la vez que se da respuesta a temas recurrentes que son cuestionados por gente corriente que no necesariamente tiene conocimientos de Derecho penal, como por ejemplo si la caza o la tauromaquia pueden ser constitutivas de delito, o si se puede cometer delito de maltrato animal por una imprudencia.

Debido a lo expuesto y a la mayor sensibilización en la sociedad en la que vivimos sobre los derechos de los animales y a la importancia que éstos han logrado en los últimos años, este podría llegar a ser un trabajo interesante no solo para aquellas personas que tengan interés en el Derecho penal, sino también para aquellas que quieran aprender cómo está regulado penalmente el maltrato animal en nuestro país.

Tras esta breve introducción, comencemos. 


\section{Evolución histórica del delito de maltrato animal en España}

Siempre ha existido cierta preocupación por el bienestar de los animales a lo largo de la historia, y prueba de ello son algunos precedentes legales históricos a favor de los derechos de los animales dignos de mencionar, aunque no se traten de materia penal en sí. Un claro ejemplo de ello fue la prohibición de la tauromaquia en 1785, aunque solamente 6 años más tarde fue levantada por Carlos IV bajo ciertas condiciones ${ }^{1}$, o la promulgación por parte del Papa Pio V en 1567 de la bula "Salutis Gregis Dominici", mediante la cual amenazaba con la excomunión a todo creyente que asistiera a los espectáculos taurinos ${ }^{3}$.

Tratando ya materia penal, en nuestro país se considera el antecedente más lejano de delito contra los animales el incorporado en el Código penal (en adelante CP) de 1928, elaborado por el General Primo de Rivera, el cual su artículo 810 tipifica como falta el maltratar públicamente a animales domésticos con una pena de multa de 50 a 500 pesetas ${ }^{4}$.

Pese a estos y otros muchos intentos en tiempos pasados de mejorar las condiciones de los animales por parte de dirigentes algo incomprendidos en aquella época, no es hasta estas últimas décadas donde la sociedad ha tomado mayor conciencia animalista (y por tanto el Derecho, pues no es más que un reflejo de la sociedad) tal y como se aprecia en los proyectos y anteproyectos del CP de 1980, 1983, 1992 y 1994, donde se vuelve a incorporar el maltrato animal como delito o falta, ya que los Códigos penales de 1932 y 1944 no albergaban ninguna regulación sobre maltrato animal. Si bien el CP de 1944 incorporaba alguna falta relativa a los animales como la sanción por arrojar animales muertos a la vía pública, o la caza y pesca ilegal ${ }^{5}$, no es al animal en estos casos a quien se protege, sino a la salud pública en el primer caso y a la propiedad en el segundo, pues era sancionable realizar tales actividades en un fundo ajeno, por lo que no podemos concluir que el CP de 1944 tuviera cierto "espíritu" animalista.

Pese a existir, como hemos visto, proyectos desde los años 80 de Códigos penales donde se proteja al animal, no es hasta el CP de 1995 cuando se hace realidad. Es destacable el hecho de que sea penalmente sancionable el maltrato animal desde hace solamente 25 años, cuando ya existía de mucho antes conciencia suficiente sobre el tema y deseos de que fuera así regulado. (Podemos destacar por ejemplo la fundación en 1976 de la Asociación de Defensa de Derechos del Animal ADDA, principal asociación/ONG animalista de nuestro país, fruto de que ya existía cierta preocupación sobre el tema). A pesar de esto, es totalmente entendible la tardanza de la regulación de este asunto en el CP, primero, porque ya hubo intentos como hemos visto, y segundo, porque el Derecho siempre avanza más lento que la sociedad, pues es inevitable que pase tiempo hasta que las creencias o moral de la sociedad se vean materializadas en él.

Volviendo al CP de 1995, en su artículo 632 se establecía con pena de multa de diez a sesenta días a quien maltratare cruelmente a animales domésticos o a cualquier otro en espectáculos no autorizados ${ }^{6}$, siendo una mera falta contra los intereses generales.

Es en 2003 cuando la modificación del CP da un paso importante en cuanto a la protección de los animales, pues en su artículo 337 se estipula una pena de prisión de tres meses a un año e inhabilitación especial de uno a tres años de profesión, oficio o comercio que tenga que ver con animales cuando se maltrate a animales domésticos con ensañamiento e injustificadamente causándoles la muerte o graves lesiones ${ }^{7}$. Se mantiene el artículo 632 del CP anterior (esta vez art. 632.2), en el que se establece que este se aplicará cuando no se incurran en los supuestos del artículo 337, siendo la pena de multa de 20 a 60 días o trabajos en beneficio de la comunidad de 20 a 30 días. Del mismo modo, se incorpora una falta por abandono de animales cuando peligre su vida o integridad. Pese a existir un cambio evidente de la regulación anterior, había voluntad de penar con mayor dureza este delito. Así, diversos grupos parlamentarios realizaron una enmienda proponiendo una nueva redacción del artículo, que en esencia se parece bastante al resultante de la modificación posterior de 2010, pero que no fue aprobada ${ }^{8}$.

La siguiente modificación vino en 2010, eliminando el término "ensañamiento", añadiendo el concepto de "animal amansado" y especificando que se causare menoscabo grave en la salud del animal", manteniendo la pena que estaba establecida, pero aumentando de esta manera los supuestos que entrarían en el tipo. No está

\footnotetext{
${ }^{1}$ PETIT, C., Fiesta y contrato, (Madrid 2011) 37, Recuperado de: https://e-archivo.uc3m.es/handle/10016/10145\#preview, consultado $7 / 02 / 2020$.

${ }^{2}$ Una bula es un documento pontificio autorizado por el Papa, que trata sobre asuntos políticos o religiosos.

${ }^{3}$ CLEMENTE, L., La legitimidad de la Tauromaquia, El Mundo, 30/03/2017, Recuperado de:

https://www.elmundo.es/cultura/toros/2017/03/30/58dc117f22601d8a778b4659.html, consultado 10/02/2020.

${ }^{4}$ BRAGE, S., Los delitos, (Valencia, 2017) 20.

${ }^{5}$ Ibidem, 21.

${ }^{6}$ Ley Orgánica 10/1995, de 23 de noviembre, del Código Penal.

${ }^{7}$ Ley Orgánica 15/2003, de 25 de noviembre, por la que se modifica la Ley Orgánica 10/1995, de 23 de noviembre, del Código Penal.

${ }^{8}$ REQUEJO, C., La protección penal, (Granada, 2010) 27 ss.

${ }^{9}$ Ley Orgánica 5/2010, de 22 de junio, por la que se modifica la Ley Orgánica 10/1995, de 23 de noviembre, del Código Penal.

84 Derecho Animal. Forum of Animal Law Studies, vol. 12/1
} 
de más mencionar el menoscabo grave de la salud, en cuanto que no se especifica que deba ser físico, abriendo entonces la posibilidad de que el resultado fuera un daño psíquico en el animal ${ }^{10}$.

La última modificación del delito objeto de estudio se produjo en $2015^{11}$, en la que a grandes rasgos se puede destacar la introducción de la explotación sexual del animal, así como el aumento de los tipos de animales protegidos. No nos detendremos más en comentar estos aspectos, pues se analizarán en detalle en los siguientes epígrafes.

\section{Bien jurídico protegido}

Se puede entender como bien jurídico todo valor de la vida humana protegido por el Derecho, integrando todo derecho o interés susceptible de protección debido a su importancia social ${ }^{12}$. Más completa parece la definición proporcionada por LUZÓN PEÑA, entendiendo los bienes jurídicos como aquellas "condiciones necesarias para el desarrollo de la vida del individuo y de la sociedad", pudiendo ser estas condiciones "objetos materiales, e inmateriales, relaciones, intereses o derechos, que en cualquier deben ser socialmente valiosos"

Cabe preguntarnos entonces cuál es el bien jurídico protegido en el delito de maltrato animal, pues existen diversos puntos de vista mencionables que abordaremos a continuación.

\subsection{Detractores}

Para empezar, existen autores que ni siquiera comparten la idea de que el delito de maltrato animal albergue un bien jurídico digno de protección penal, bien porque entienden que la penalización del maltrato animal ha sido usado como instrumento político, legislando de esta manera de forma simbólica, bien porque las sanciones administrativas son suficiente protección hacia los animales sin tener que pasar por el Derecho penal, que debe ser utilizada como ultima ratio, o bien porque el concepto de "animales domésticos" al no estar recogido en la Constitución, no debe ser protegido entonces mediante el Derecho penal ${ }^{14}$.

En cuanto a esta última postura, nada más lejos de la realidad. Existen conductas castigadas por el Derecho penal que evidentemente no gozan de protección en la Constitución, ya que es materialmente imposible que la Constitución recoja o mencione en esencia todos los tipos delictivos que hayan de estar en el Código penal, o todos los bienes jurídicos que hayan de ser tutelados por éste. Por ello, es una posición bastante difícil de defender. En esta misma línea, DÓMENECH PASCUAL señala que, aunque algún interés humano no figure en la Constitución, no quiere decir que no merezca tutela, ya que es imposible que la Constitución de 1978 fuera capaz de prever los intereses actuales y futuros para acogerlos en ella, siendo los demás intereses inconstitucionales y dejándoles fuera de protección alguna ${ }^{15}$.

Las dos primeras posiciones son también rebatibles, pues, aunque es cierto que el Derecho penal deba actuar en última instancia bajo el principio de subsidiariedad, también es cierto bajo el mismo principio que debe actuar cuando mediante otros métodos no sea posible frenar o disuadir determinadas conductas ${ }^{16}$ y siempre y cuando exista un ataque grave a un bien jurídico que deba ser protegido por éste. En este caso, las sanciones administrativas no parecen suficiente para acabar con esta lacra, ya que de hecho, ni siquiera estar tipificado como delito en los términos en los que está, no parece disuadir demasiado para que no se cometa este delito, pues año tras año no deja de crecer el número de casos de maltrato animal ${ }^{17}$, de ahí que parte de la doctrina y buena parte de la sociedad crea conveniente no solo que esté tipificado como delito a diferencia de

\footnotetext{
${ }^{10}$ REQUEJO, C., El delito de maltrato a los animales tras la reforma del Código Penal por la Ley Orgánica 1/2015, de 30 de marzo en Derecho Animal, 6 (2), (2015), 3, Recuperado de:

https://idus.us.es/bitstream/handle/11441/86277/El\%20delito\%20de\%20maltrato....pdf?sequence=1, consultado 11/02/2020.

${ }^{11}$ Mediante la Ley Orgánica 1/2015, de 30 de marzo, por la que se modifica la Ley Orgánica 10/1995, de 23 de noviembre, del Código Penal.

${ }^{12}$ DE VICENTE, R., Vademécum de derecho penal, $5^{\text {a }}$, (Valencia, 2018) 74.

${ }^{13}$ LUZÓN, D.M., Lecciones, (Valencia, 2016) 169, 13/16.

${ }^{14}$ BRAGE, S., Los delitos, (Valencia, 2017) 48. Menciona diversos autores defensores de estas ideas como MARTÍNEZ-BUJÁN, C., BAUCELLS, J., DÍAZ-MAROTO, J. o FARALDO, P.

${ }^{15}$ DOMENECH G.,, Revista Interdisciplinar de Gestión Ambiental, 74, (2005), 24 citado por BRAGE, S., Los delitos, (Valencia, 2017) 49, nota a pie 127.

${ }^{16}$ LUZÓN, D.M., Lecciones, (Valencia, 2016) 14, 1/49, menciona que una de las funciones del Derecho penal es en efecto el de prevención, consiguiéndose entre otros modos mediante el carácter disuasorio que tiene la amenaza de las penas.

${ }^{17}$ ELCACHO, J., Las condenas por maltrato animal se han multiplicado por 14 en la última década, La Vanguardia, 06/08/2019, Recuperado de: https://www.lavanguardia.com/natural/20190806/463897610720/estudio-seo-birdlife-denuncias-delitosambientales.html, consultado 15/02/2020.
} 
lo que dicen estos autores ${ }^{18}$, sino que creen en la necesidad de penar incluso con mayor dureza este delito ${ }^{19}$. Si bien el aumento del número de casos de este delito pudiera verse explicado, entre otras cosas, por el mayor número de denuncias interpuestas, esto también denotaría una preocupación y sensibilización creciente en la sociedad sobre el tema.

Por último, respecto a que es un delito que se tipificó como instrumento político o de manera simbólica, pese a poder haber sido en parte un mecanismo político para obtener más votos o rédito político, difícilmente se puede discutir en vista de la definición del bien jurídico protegido, que los animales encajarían a la perfección en ésta al ser un elemento socialmente necesario y valioso para el desarrollo de la vida de los individuos y de la sociedad. Que sea criticable en ese sentido, no quiere decir que sea ilegítimo haber tipificado como delito el maltrato animal. Por ello, no considero válido el argumento de que no debe ser considerado delito porque se haya legislado en pro únicamente de conseguir más votos.

Entre los demás autores que sí defienden la idea de la existencia en este delito de un bien jurídico que deba ser protegido por el Derecho penal, existen diferentes corrientes de las cuales pasaremos a exponer las más relevantes para ser posteriormente comentadas.

\subsection{Moral pública}

En primer lugar, existe una doctrina antigua que defiende que el bien jurídico es la moral pública y las buenas costumbres. Ésta defiende que el maltrato hacia los animales puede llevar a maltrato contra las personas, por lo que debe castigarse por su peligrosidad anticipada hacia la sociedad y sus individuos y no por el maltrato hacia el animal en sí. En este sentido no sería el animal más que un objeto sobre el que recae la acción, siendo una concepción muy antropocéntrica del delito.

Esta posición totalmente antropocéntrica es una concepción errónea. Esto es así debido a que se estaría relegando el maltrato que se realiza al animal en sí a un segundo plano y castigando la peligrosidad del individuo que lo realiza por la potencialidad intrínseca que encierra este comportamiento, que en su ascenso delictivo puede suponer la antesala de la lesión de personas. De esta forma, ni siquiera se estaría penando una conducta que por sí sola sea de riesgo directo para un bien jurídico, sino que se castigaría un peligro hipotético futuro imposible de medir y probar. Existen sobre este tema diversos estudios ${ }^{20}$ que relacionan el maltrato animal con una futura delincuencia, y de manera retrospectiva, relacionan a numerosos delincuentes con episodios de maltrato animal en sus infancias, si bien estos estudios son criticados por su poco rigor y metodología. De esta manera, llega a ser bastante difuso que se pudiera considerar siquiera ese supuesto peligro como una razón para encontrar un bien jurídico que deba ser protegido bajo tutela penal, vulnerando de esta manera el principio de exclusiva protección de bienes jurídicos. No obstante, esta doctrina la considero una herramienta muy útil para convencer en el ámbito político a todo aquel que no esté conforme con la tipificación de este delito por no considerar a los animales dignos de ninguna protección, dándoles un motivo "humanamente egoísta" por el que legislar tipificando el maltrato animal. Pero ese es un tema que no nos incumbe.

\subsection{Sentimientos de los seres humanos}

Otra corriente defiende que el bien jurídico es el sentimiento de amor y compasión hacia los animales. Esta corriente defiende que, en efecto, son estos sentimientos de amor, benevolencia y piedad los bienes jurídicos protegidos en el delito, siendo los animales un mero objeto material en el que recae el delito y no titulares de ningún derecho ${ }^{21}$, tal como ocurre en la postura anteriormente vista.

En cuanto a esta segunda postura, es rebatible en el sentido que para que estos sentimientos pudieran ser ofendidos, deberían de tratarse de conductas que tuvieran que llevarse a cabo necesariamente en público ${ }^{22}$, de lo contrario no podrían verse vulnerados los sentimientos de piedad o benevolencia al no poder ser siquiera consciente por parte de nadie de que se está llevando a cabo ningún tipo de maltrato, exigencia que no se aprecia en el tipo.

\footnotetext{
${ }^{18} \mathrm{~V}$. supra nota a pie 14

${ }^{19}$ REQUEJO, C., El delito de maltrato a los animales, LL, 2008-2, 1773 ss, citado por GARCÍA, M., El delito de maltrato a los animales. El maltrato legislativo a su protección, en Revista de Bioética y Derecho, (2015), 50, Recuperado de: https://www.redalyc.org/pdf/783/78343122008.pdf, consultado 13/02/2020. Este autor coincide también con la idea que él cita.

${ }^{20}$ JOSA, J.M - MAKOWSKI, M., Información Veterinaria, (2009), 17, Recuperado de:

https://www.researchgate.net/profile/Juan_Josa/publication/325767085_El_maltrato_animal_como_indicador_de_riesgo_social/link s/5b22c719458515270fcca55f/El-maltrato-animal-como-indicador-de-riesgo-social.p pdf, consultado 13/02/2020.

${ }^{21}$ BRAGE, S., Los delitos, (Valencia, 2017) 52 ss.

22 HAVA, E., La protección del bienestar animal a través del Derecho penal en EPCrim, 31, (2011), 284, Recuperado de: https://minerva.usc.es/xmlui/bitstream/handle/10347/7319/261-306.pdf?sequence=1\&isAllowed=y, consultado 15/02/2020.
}

86 Derecho Animal. Forum of Animal Law Studies, vol. 12/1 


\subsection{Derechos subjetivos de los animales}

La tercera posición doctrinal señala que el bien jurídico protegido son los derechos subjetivos de los animales. De este modo, se entendería a los animales como verdadero sujeto pasivo del delito y no como un mero objeto sobre el que recae la acción, como hemos visto hasta ahora. Admitir que los animales pueden ser sujetos pasivos de los delitos podría llevar a pensar a alguien que también pueden llegar a ser sujetos activos. Sin embargo, esto sería un tanto absurdo, pues los animales no pueden actuar con imprudencia ni dolo como exige el CP, sino instintivamente, y no se puede castigar penalmente una acción instintiva. Sin embargo, esto se resolvería de una manera muy sencilla, y es estableciendo que los animales tienen derechos pero no obligaciones, equiparándose por ejemplo a un recién nacido ${ }^{23}$.

\subsection{El bienestar animal}

La última corriente defiende que el bien jurídico protegido es el bienestar animal. Señala HAVA GARCÍA $^{24}$ que, aunque los sentimientos de amor y compasión a los animales fueron los que propiciaron que se tipificara como delito el maltrato animal, el papel de esos sentimientos se acaban en el momento en que se tipifica, siguiendo de este modo el tipo por su propio camino. Pone un ejemplo muy ilustrativo, y es que al igual que los delitos contra el patrimonio histórico fueron originados por el sentimiento que pudiera inspirar el contemplar tales obras, está claro que el bien jurídico protegido son las propias obras y no el sentimiento que se tenga hacia ellas. De este modo, en el delito de maltrato animal el bien jurídico protegido sería el animal, y más concretamente su bienestar.

Coincido con esta corriente en el sentido de que, pudiéndose entender al animal como el bien jurídico protegido, es inevitable que esta protección tenga un origen antropocéntrico. Esto se puede ver en los animales que han estado y están recogidos en el tipo, partiendo de una situación en la que solamente estaban protegidos los animales domésticos a una situación en la que, resumidamente, están protegidos todos los animales que no sean salvajes, pudiéndose observar que la conducta de maltratar animales está castigada solamente cuando se trata de animales por los que el ser humano, debido a la relación que tiene con ellos (ya sea por cercanía, por estar bajo su cuidado o incluso por relación de amistad), siente pena o cierto sentimiento de empatía que hace que se perciba el maltrato como una acción que debe ser castigada. Por ejemplo, no es percibido con la misma piedad o empatía que un ciervo reciba dos disparos y se quede malherido a que lo haga un perro, un gato o un caballo. De esta forma, aunque en efecto se considere que son los propios animales los que están protegidos y no los sentimientos de las personas, éstos toman una elevada importancia a la hora de tipificar el delito y delimitar el propio bien jurídico. Bajo una línea parecida se pronuncia MENÉNDEZ DE LLANO ${ }^{25}$, que sostiene que los animales protegidos del maltrato son solamente los descritos en el tipo debido al hecho de que dependen directa o indirectamente del ser humano ${ }^{26}$.

Sin embargo, HAVA GARCÍA termina con la conclusión de que los animales no tienen ningún derecho a la integridad física o psíquica, ni a la vida ${ }^{27}$. Y, no obstante, ello no explicaría entonces por qué se castiga con mayor pena el maltrato animal cuando el resultado de la acción es la muerte del animal. Castigando con mayor dureza un resultado de muerte que uno de lesiones, se está admitiendo implícitamente que existen derechos tutelados de los animales, y que en efecto no se puede castigar de la misma manera una vulneración a su derecho a la integridad física o psíquica que una vulneración a su derecho a la vida, el cual tiene mayor valor y por ello está más protegido con una pena mayor. Señala esta autora que el motivo por el cual no tienen ningún derecho los animales es porque ello frustraría cualquier necesidad humana en la que ellos fueran necesarios, como por ejemplo comer. Personalmente y respecto a esta posición, no parece incompatible la idea de que los animales tengan derechos subjetivos y los humanos tengan determinadas necesidades que se deban satisfacer mediante la vulneración de ellos ${ }^{28}$. Simplemente hemos de tener en cuenta el conflicto de

\footnotetext{
${ }^{23}$ BRAGE, S., Los delitos, (Valencia, 2017) 55.

${ }^{24}$ HAVA, E., La protección del bienestar animal a través del Derecho penal en EPCrim, 31, (2011), 289 ss, Recuperado de: https://minerva.usc.es/xmlui/bitstream/handle/10347/7319/261-306.pdf?sequence=1\&isAllowed=y, consultado 15/02/2020.

${ }^{25}$ MENÉNDEZ, N., "El maltrato animal tras la reforma del Código Penal. Ex

LO 1/2015, de 30 de marzo, 6, citado por RIOS, J.M., Comentario en relación al maltrato de animales en la nueva reforma del Código Penal español en Derecho Animal, 6 (2), (2015), 6, nota a pie 12, Recuperado de: https://revistes.uab.cat/da/article/view/v6-n2-rios/76, consultado 18/02/2020.

${ }^{26}$ En contra, BLANCO, I., Comentarios, (Navarra, 2015) 180, quien considera que no entra en juego ningún referente propio de las personas.

${ }^{27}$ HAVA, E., La protección del bienestar animal a través del Derecho penal en EPCrim, 31, (2011), 291 ss, Recuperado de: https://minerva.usc.es/xmlui/bitstream/handle/10347/7319/261-306.pdf?sequence=1\&isAllowed=y, consultado 23/02/2020.

${ }^{28}$ En este sentido, RIOS, J.M., Nuevos tiempos para el delito de maltrato de animales en RECPCrim, 18, (2016), 22, Recuperado de: https://pdfs.semanticscholar.org/e947/9b2c7239795a8b6b6fefb8eaccc7d5bfa931.pdf, consultado 20/03/2020, expresa que no se
} 
derechos o necesidades existente entre humanos y animales, y considerar cuál de ellos es más importante y en qué circunstancia, siempre bajo criterios de proporcionalidad. En este sentido, las causas de justificación entrarían en juego, figura que analizaremos más adelante, abriendo la posibilidad a que, por ejemplo, se pueda matar animales bajo el pretexto de alimentarnos, sin que por ello se dejen de reconocer los derechos subjetivos de los animales.

\subsection{Posición defendida}

Por todo lo expuesto y pese a coincidir en mayor medida con la última autora en lo expuesto en párrafos anteriores, considero que lo más acertado es considerar que el bien jurídico protegido son los derechos subjetivos de los animales delimitados bajo un marco antropocéntrico. Descartando que sea el mero "bienestar animal" sin que tengan ningún derecho los animales, y descartando que sean los derechos subjetivos de los animales en general.

Descarto la idea de que el bien jurídico protegido sea el "bienestar animal", ya que esta corriente está en contra de la idea de que existan derechos subjetivos en los animales. ¿Qué es el bienestar animal sino el derecho a preservar la vida y la integridad física y/o psíquica ${ }^{29}$ ? Otorgándoles el "derecho" al bienestar, no es otra cosa que admitir implícitamente que los animales son titulares de derechos subjetivos.

Descarto del mismo modo la idea de que el bien jurídico sean los derechos subjetivos de los animales en general, pues de ser esta la idea correcta, serían todos los animales los protegidos por el Derecho penal incluidos los salvajes (pues no es menos animal un ciervo, por seguir el ejemplo anterior, que un caballo), pero la realidad no es esa, ya que el caballo sí está protegido por la tutela penal mientras que el ciervo, en un primer momento, no lo estaría al ser salvaje.

Que el bien jurídico protegido no sean los derechos subjetivos de todos los animales, no quiere decir que este no deba ser el camino a seguir en futuras reformas del CP. También que el bien jurídico protegido tenga, como se ha expuesto, concepciones antropocéntricas, no es incompatible con la idea de pensar que los animales (también los salvajes) sean o deban ser titulares de derechos subjetivos por el hecho de existir y sentir. Por ello, pese a describir el bien jurídico protegido como una mezcla entre los propios derechos de los animales y la influencia de los sentimientos o relación de los humanos con ellos, creo conveniente que se legisle en pro de que el bien jurídico protegido sean en efecto los derechos subjetivos de todos los animales, sin que esa concepción antropocéntrica entre en juego. De esta manera, se incluirían también a los animales salvajes, ya que estos tienen la misma capacidad de sufrir que los animales ya protegidos, debiendo ser el objetivo principal de la tipificación del delito defender sus derechos subjetivos y por tanto su derecho a no sufrir innecesariamente.

Por último y a modo de curiosidad, bajo esta última premisa argumentaba el filósofo JEREMY BENTHAM, siendo de los primeros en criticar la tiranía del hombre frente a los animales, exponiendo que la cuestión para otorgar derechos a los animales no era si los animales razonaban o hablaban, sino si podían sufrir $^{30}$.

\section{Tipo básico}

\section{"Artículo 337:}

Será castigado con la pena de tres meses y un día a un año de prisión e inhabilitación especial de un año y un día a tres años para el ejercicio de profesión, oficio o comercio que tenga relación con los animales y para la tenencia de animales, el que por cualquier medio o procedimiento maltrate injustificadamente, causándole lesiones que menoscaben gravemente su salud o sometiéndole a explotación sexual, a

a) un animal doméstico o amansado,

b) un animal de los que habitualmente están domesticados,

c) un animal que temporal o permanentemente vive bajo control humano, o

puede argumentar que los animales no tengan derechos subjetivos, si bien no se pueden colocar en el mismo plano que los derechos subjetivos de los hombres.

${ }^{29}$ REQUEJO, C., El delito de maltrato a los animales tras la reforma del Código Penal por la Ley Orgánica 1/2015, de 30 de marzo en Derecho Animal, 6 (2), (2015), 9, Recuperado de:

https://idus.us.es/bitstream/handle/11441/86277/El\%20delito\%20de\%20maltrato....pdf?sequence=1, consultado 26/02/2020. Esta autora defiende la idea de que el bien jurídico protegido es la integridad física y psíquica y vida del animal.

30 BENTHAM, J., An introduction to the Principles of Morals and Legislation, 1789, 308 ss, Recuperado de: https://books.google.es/books?hl=es\&lr=\&id=vCI0AQAAMAAJ\&oi=fnd\&pg=PA1\&dq=jeremy+bentham + introduction + to + the + pri nciples + of + morals\&ots $=$ adeNZq-mpR\&sig=mIEshgfwJCYe-xse9btHXWtPpW4\#v=onepage \&q\&f $=$ false

88 Derecho Animal. Forum of Animal Law Studies, vol. 12/1 
d) cualquier animal que no viva en estado salvaje."

\subsection{Tipo objetivo \\ 4.1.1. Sujeto activo}

Cualquier persona puede cometer este delito. No es necesario ser dueño de los animales ni que éstos estén bajo su protección. Es un delito en el cual no es necesario tampoco que sea de primera mano ${ }^{31}$, pues no se exige que el sujeto activo maltrate directamente, sino que bastaría, por ejemplo, con azuzar al animal con otros para que entre ellos se lesionen o maten. Así pues, una pelea de perros en la que se lesionan entre ellos mientras los dueños los animan a que lo hagan, encajaría en el tipo.

Es mencionable que ningún autor haya discutido hasta el momento la problemática que puede existir a la hora de determinar quién es el autor en la conducta típica de someter a explotación sexual al animal. En esta modalidad cabe preguntarse si el sujeto activo es únicamente quien mantiene relaciones sexuales con el animal, o si también lo es quien recibe un precio a cambio de que esto suceda, o ambos. Por analogía en términos estrictamente interpretativos respecto al artículo $188 \mathrm{CP}$, el sujeto activo de esta conducta típica serían ambos, pues en este delito relativo a la explotación sexual en seres humanos se castiga tanto al que facilita la prostitución mediando ánimo de lucro como al que solicita la relación sexual a cambio de un precio $^{32}$. Pese a que la analogía no está permitida en Derecho Penal, esta es referida solamente a la aplicación de una ley en otro supuesto semejante, pudiéndose aplicar en materia de interpretación, recurriendo a la semejanza de algún término de ambos preceptos para poder interpretarlo ${ }^{33}$.

La conducta típica relativa a la explotación sexual se verá más adelante en mayor detalle.

\subsubsection{Sujeto pasivo}

Los sujetos pasivos del delito son los animales descritos por el tipo. Se ha discutido sobre si son meros elementos descriptivos o bien normativos, teniendo que remitirnos a las leyes administrativas para determinar qué se quiere decir con cada tipo de animal. Esto no es posible ya que cada ley autonómica define de manera sustancialmente distinta determinados conceptos como el de "animal doméstico". No estamos por tanto ante una norma penal en blanco, ya que no remite a ninguna otra normativa para establecer en este supuesto cuál sería el sujeto pasivo, sino que viene establecido en la redacción del propio artículo ${ }^{34}$.

El delito en su apartado 1. a) menciona a los animales domésticos o amansados. En este sentido se deben interpretar estos conceptos como aquellos animales que necesitan de la mano del hombre para subsistir, por lo que además de los animales de compañía, se incluyen a todos aquellos de renta, abasto o trabajo ${ }^{35}$. De igual modo se deben interpretar estos conceptos de una manera amplia, englobando de igual modo a todos aquellos animales que en su origen fueron salvajes pero que ahora no lo son, como por ejemplo un camaleón o iguana que se tienen por mascota, o animales de circo tal como monos, leones, tigres o elefantes ${ }^{36}$.

En segundo lugar, nos encontramos con el apartado 1. b), donde se menciona a los animales que estén habitualmente domesticados. Esta categoría se introdujo para acallar viejas controversias de doctrina y jurisprudencia sobre si, por ejemplo, un gato callejero merecía o no protección penal. En efecto, no tiene sentido otorgar protección a aquel gato que vive en una casa y no al que vive en la calle, llegando incluso a estar más expuesto el callejero al maltrato. Bajo esta redacción quedarían entonces amparados además de los gatos callejeros, cualquier animal que acostumbre a vivir bajo la compañía del hombre, como puede tratarse

\footnotetext{
${ }^{31}$ BRAGE, S., Los delitos (Valencia, 2017) 62.

${ }^{32}$ Cabe añadir la interpretación por parte de DE VICENTE, R., Vademécum de Derecho penal, 5a (Valencia, 2018) 368, al artículo 177 bis CP, en la que expresa que lo que se intenta es recoger como delictivas todas y cada una de las conductas que favorezcan la explotación sexual, por lo que cabría preguntarnos si en el supuesto del artículo $337 \mathrm{CP}$, se podría considerar reo del delito de explotación sexual animal a quien por ejemplo transporta al animal o animales de un punto a otro con el objetivo de que éstos sean sometidos a explotación sexual.

${ }^{33}$ LUZÓN, D.M., Lecciones, (Valencia, 2016) 73, 6/24. Otros autores como RIBAS, E.R., Interpretación extensiva y analogía en Derecho Penal en REDPCrim, 12, (2014), 116 ss, Recuperado de:

http://e-spacio.uned.es/fez/eserv/bibliuned:revistaDerechoPenalyCriminologia-2014-12-

5010/Interpretacion_extensiva_analogia.pdf, consultado 05/03/2020, expone que el legislador no puede describir todos los supuestos con exactitud en todas las leyes, recurriendo a fórmulas generales al igual que hace uso de palabras imprecisas, por lo que entiende necesaria la analogía interpretativa en el ámbito penal.

${ }^{34}$ HAVA, E., La protección del bienestar animal a través del Derecho penal en EPCrim, 31, (2011), 293 ss, Recuperado de: https://minerva.usc.es/xmlui/bitstream/handle/10347/7319/261-306.pdf?sequence=1\&isAllowed=y, consultado 23/02/2020; REQUEJO, C., El delito de maltrato a los animales tras la reforma del Código Penal por la Ley Orgánica 1/2015, de 30 de marzo en Derecho Animal, 6 (2), (2015), 11, Recuperado de:
}

https://idus.us.es/bitstream/handle/11441/86277/El\%20delito\%20de\%20maltrato....pdf?sequence=1, consultado 26/02/2020.

${ }^{35}$ BRAGE, S., Los delitos, (Valencia, 2017) 65.

${ }^{36}$ Ibidem, 66. 
de un perro abandonado, o incluso un caballo salvaje $\mathrm{e}^{37}$.

En tercer lugar, el apartado 1. c) alude a un animal que viva temporal o permanentemente bajo control humano. Este apartado se ha redactado también con la intención de recoger expresamente a animales como los de trabajo en una granja sin que hubiera ningún género de dudas como las hubiera podido haber bajo las redacciones anteriores. También se estaría dando protección expresa a animales anteriormente mencionados, tales como leones, tigres, delfines, orcas, o cualquier animal naturalmente salvaje que esté en cautiverio y bajo control humano por diversas razones ${ }^{38}$, como puede ser su exhibición en un zoológico o su estancia en un centro de recuperación de animales rescatados ${ }^{39}$.

En último lugar, nos encontramos con el apartado 1. d), el cual nombra a los animales que no vivan en estado salvaje. Se trata de un concepto amplio con una acotación en sentido negativo. Debemos entender al animal salvaje como aquel que desarrolla todo o casi todo su proceso vital sin la intervención del hombre ${ }^{40}$, o aquel que no pertenece a especies acostumbradas a la convivencia con el hombre y que no depende de él ${ }^{41}$. Parece clara la tendencia de definir al animal salvaje básicamente como aquel que ni vive con el ser humano ni necesita de él para subsistir.

Tras leer estas líneas, podemos deducir que prácticas como la caza no encajan en el tipo y por tanto no es una conducta delictiva al amparo del artículo $337 \mathrm{CP}$, al no proteger a los animales que son objeto de ella, es decir, los animales salvajes. Todo ello sin perjuicio de que mediante esta práctica se puedan cometer otros hechos delictivos contemplados en el Capítulo III y siguientes del Título XVI del CP, relativos a delitos contra la fauna, los recursos naturales y el medio ambiente, y sin perjuicio también de la existencia de otras conductas constitutivas de este delito derivadas de la caza, como puede ser matar a los galgos u otros perros una vez acabada la temporada de caza.

Los animales de circo también están protegidos ya que dependen del ser humano al vivir en cautiverio tal y como hemos visto, si bien esto no quiere decir que la celebración de circos con animales como tal sea delito. Solamente lo será en la medida en la que exista maltrato hacia ellos, ya sea en el propio espectáculo o en las prácticas que puedan realizar para amaestrarles, debido a que exhibirlos en sí no está tipificado como delito. Las conductas constitutivas de delito las analizaremos más adelante.

También podemos deducir que el toro es un animal amparado por este delito, al no vivir en estado salvaje y depender de la mano del hombre para subsistir. Analizaremos la tauromaquia en el epígrafe relativo a las causas de justificación.

Concluyendo este epígrafe y siguiendo la idea expuesta en el apartado del bien jurídico protegido, en la que se expresa que deberían ser también los animales salvajes protegidos por la tutela penal con base en que el bien jurídico protegido deberían ser los derechos subjetivos de todos los animales, cabe destacar la legislación alemana en la que se protege a los animales vertebrados (se utiliza la expresión alemana wirbeltier), ampliando así el rango de animales protegidos a todos aquellos que posean columna vertebral, desarrollo simétrico dual y sistema nervioso central ${ }^{42}$. De este modo, el modelo alemán sería un ejemplo a seguir para la legislación española, dando un paso hacia adelante en favor de los derechos de todos los animales.

\subsubsection{Acción o conducta}

“(...) el que por cualquier medio o procedimiento maltrate injustificadamente, causándole lesiones que menoscaben gravemente su salud o sometiéndole a explotación sexual, a (...)"

Tal y como está redactado el delito, existen dudas sobre cuál es la conducta típica, existiendo dos opciones: la primera de ellas entendería que la acción típica son en realidad dos, siendo el maltrato injustificado que causara lesiones que menoscaben gravemente la salud por un lado, y someter a explotación sexual por otro; la segunda opción es entender el maltrato injustificado como común denominador de ambas conductas, ocasionando lesiones que menoscaben gravemente la salud por un lado y explotando sexualmente

\footnotetext{
${ }^{37}$ Ibidem, $67 \mathrm{ss}$.

${ }^{38}$ Señala RIOS, J.M., Comentario en relación al maltrato de animales en la nueva reforma del Código Penal español en Derecho Animal, 6 (2), (2015), 6, Recuperado de: https://revistes.uab.cat/da/article/view/v6-n2-rios/76, consultado 18/02/2020, que también estarían amparados animales que hayan sido despojados de sus hábitats naturales de manera ilegal para forzarles a ser mascotas, llevando aparejada su correspondiente sanción administrativa.

${ }^{39}$ BRAGE, S., Los delitos, (Valencia, 2017) 68

${ }^{40}$ REQUEJO, C., La protección penal, (Granada, 2010) 40. Esta autora para ofrecer esta definición, se ayuda de la Ley andaluza $8 / 2003$ de Flora y Fauna Silvestres, más concretamente de su artículo 2.

${ }^{41}$ BRAGE, S., Los delitos, (Valencia, 2017) 69.

42 Ibidem, 63, nota a pie 172.

90 Derecho Animal. Forum of Animal Law Studies, vol. 12/1
} 
al animal por otro ${ }^{43}$.

En cualquier caso, las lesiones que menoscaben gravemente la salud han de ser injustificadas, mientras que la explotación sexual dependerá de la interpretación que se dé al tipo, pudiendo incluir o excluir el término "maltratar injustificadamente" a esta conducta.

Personalmente, me decanto por la primera interpretación ${ }^{44}$. Pese a que puedan existir causas de justificación que excluyan del tipo el menoscabar gravemente la salud del animal y que veremos más adelante, como por ejemplo comer carne animal, no existe, sin embargo, ninguna justificación imaginable que permita explotar sexualmente a los animales. Admitiendo como válida la segunda interpretación de la acción típica, se estaría abriendo la puerta a casos donde explotar sexualmente a un animal estaría justificado y por tanto fuera del tipo. Creo más conveniente interpretarlo de la primera forma, castigando en todos los casos la explotación sexual al animal, aún incluso cuando esta no conlleve sufrimiento alguno ${ }^{45}$, ya que el término "maltrato" también se vería excluido en esta conducta. Me decanto por esta opción ya que, como acabo de mencionar, no hay ninguna circunstancia imaginable en la que los derechos o intereses de los humanos entren en conflicto con la integridad sexual del animal, justificando así la explotación sexual de animales. Considero carente de sentido que el legislador haya siquiera considerado la posibilidad de justificar (y por tanto excluir del tipo) esta deleznable conducta, a la que se podría considerar una aberración de la naturaleza ${ }^{46}$. Aun existiendo algún supuesto concreto donde quepa alguna causa de justificación genérica de las recogidas en el $\mathrm{CP}$, carece de lógica exigir en el tipo que la conducta sea "injustificable", pues como en cualquier otro tipo penal, las causas de justificación mencionadas se pueden aplicar sin tal exigencia. Al no exigir por tanto que exista maltrato injustificado, no es necesario que para consumar el delito deba mediar maltrato en el acto de explotar sexualmente al animal.

Independientemente de que el término "injustificadamente" se incluya en la explotación sexual, en el maltrato que menoscabe gravemente la salud del animal se va a exigir siempre que sea injustificado. Por tanto, habrá conductas que bajo causas de justificación sean excluidas del tipo. Estas las analizaremos más adelante en el apartado de causas de justificación.

Analizado esto, vamos a ver qué se entiende por "maltrato". Según la doctrina mayoritaria, el maltrato es lo contrario a tratar bien. Pese a ser simplista esta definición, la considero acertada al ser descrita en sentido negativo, acuñando de esta manera cualquier trato que no sea acorde a un trato óptimo. Sin embargo, hemos de tener en cuenta unos criterios para el maltrato distintos a los que mantendríamos si se tratara de seres humanos $^{47}$. Así, por ejemplo, no se podría considerar maltrato el dar comida de baja calidad a nuestros animales, o no dotar de sombra a nuestros caballos en verano, pues se estaría haciendo un uso realmente extensivo del concepto "maltrato", yendo así en contra del principio de mínima intervención del Derecho penal ${ }^{48}$. Cabe mencionar que el maltrato no tiene por qué ser habitual, bastando un solo acto para que se consume el delito ${ }^{49}$. Un sector de la doctrina considera que para que exista maltrato se le debe causar sufrimiento al animal ${ }^{50}$, si bien parece algo lógico que el animal deba sufrir para que se pueda considerar alguna conducta como maltrato, esto excluiría del tipo determinadas conductas en las que el sujeto activo anestesiara al animal para, por ejemplo, verterle un ácido por la piel sin causarle ningún tipo de daño.

Refiriéndonos a la expresión incluida en el tipo "por cualquier medio o procedimiento", esta quiere decir que, en efecto, la manera en la que se lleve a cabo la conducta es irrelevante. Esto permite que el delito se pueda cometer también por omisión. Un ejemplo de comisión por omisión de este delito podría ser el dueño que no alimenta a su perro, dejando que se muera de hambre, o aquel que pudiendo refugiar a su caballo, deja que se muera de frío a la intemperie. Para que se pueda cometer el delito por omisión se debe exigir encontrarse en posición de garante, poseedor o cuidador del animal ${ }^{51}$.

\footnotetext{
${ }^{43}$ Ibidem, 70.

${ }^{44}$ En contra, BRAGE, S., Idem; A favor de esta interpretación, RIOS, J.M., Comentario en relación al maltrato de animales en la nueva reforma del Código Penal español en Derecho Animal, 6 (2), (2015), 4, Recuperado de: https://revistes.uab.cat/da/article/view/v6-n2-rios/76, consultado 26/02/2020.

45 En efecto, como comenta BLANCO, I., Comentarios, (Navarra, 2015) $182 \mathrm{ss,} \mathrm{de} \mathrm{los} \mathrm{debates} \mathrm{parlamentarios} \mathrm{se} \mathrm{deduce} \mathrm{que} \mathrm{la}$ intención del legislador es sancionar la explotación sexual sin más, sin que tenga que mediar un "maltrato injustificado", ya que muchas de las enmiendas pretendían sancionar cualquier tipo de acto de naturaleza sexual con animales. No obstante, como estamos viendo, la redacción final deja lugar a dudas.

${ }^{46}$ Bajo esta línea se encuentra también la Ley de protección de los animales alemana, la cual prohíbe "utilizar a un animal para actos sexuales (...) y con ello obligarle a un comportamiento antinatural".

${ }^{47}$ BLANCO, I., Comentarios, (Navarra, 2015) 181.

${ }^{48}$ BRAGE, S., Los delitos, (Valencia, 2017) 71.

${ }^{49}$ SERRANO, M.D., El maltrato de animales en REDPCrim, 2, (2004), 522, Recuperado de:

http://e-spacio.uned.es/fez/eserv/bibliuned:revistaDerechoPenalyCriminologia-2004-extra2-5140/Documento.pdf, consultado 25/02/2020.

${ }^{50}$ BRAGE, S., Los delitos, (Valencia, 2017) 71.

${ }^{51}$ REQUEJO, C., La protección penal, (Granada, 2010) 45. En los mismos términos, la SAP Granada 1593/2016 de 27 de septiembre,
} 
Del mismo modo es un delito que como se ha comentado anteriormente en lo referido al sujeto activo, no debe ser necesariamente de primera mano, ya que al amparo de "por cualquier medio o procedimiento", cabe la posibilidad de realizar el maltrato, por ejemplo, azuzando a animales para que se lesionen entre ellos. A propósito de esto, circula por la red un vídeo de un grupo de personas en Indonesia que, estando cerca de un cocodrilo, atraen con comida a un cerdo hambriento hasta éste, con la intención de que el cocodrilo se lo coma vivo y grabarlo todo, sucediendo al final de esta forma. Sin pararnos a analizar los demás elementos del tipo, esta es una conducta que encajaría dentro de él, pues, aunque no son ellos quienes causan directamente la muerte al animal, al poder realizar el tipo "por cualquier procedimiento" no debiendo ser necesariamente de propia mano, lo realizan mediante el engaño al cerdo que cree que va a comer, ocasionando deliberadamente que sea el cocodrilo quién otorgue una muerte dolorosa al animal.

\subsubsection{Maltrato con resultado de lesiones}

Esta conducta viene marcada por el maltrato injustificado que menoscabe gravemente la salud del animal. Estamos por tanto ante un delito de resultado, en el que se exige que el resultado sean lesiones que menoscaben gravemente la salud del animal. Hay que entender por tanto a qué nos referimos con "menoscabar gravemente la salud". La doctrina establece que se deben seguir los mismos criterios que se siguen en el delito de lesiones hacia las personas ${ }^{52}$. Esto viene a decir que se debe exigir una primera asistencia facultativa y un tratamiento veterinario o quirúrgico. De solamente existir una primera asistencia facultativa, se podría integrar en el tipo atenuado, mientras que si ocasionara lesiones más graves se podría integrar en el tipo agravado ${ }^{53}$, ambos analizados más adelante en sus respectivos epígrafes.

Que no se especifique expresamente si el menoscabo deba ser físico o psíquico, hace que exista la posibilidad de que un grave menoscabo psíquico entre también en el tipo. Así, si alguien, por ejemplo, encerrara a su perro durante largos periodos de tiempo en una jaula donde casi no pudiera ni moverse, no estaría maltratando físicamente sino psicológicamente al animal ${ }^{54}$. No obstante, es un resultado muy complicado de probar en la práctica, por lo que es difícil aplicarlo en la realidad ${ }^{55}$.

\subsubsection{Explotación sexual}

De acuerdo con la interpretación defendida al principio del epígrafe, para consumar el delito referente a la explotación sexual del animal no es necesario la exigencia de que sea un maltrato injustificado, a diferencia de la conducta de maltrato que causa graves lesiones. Estaríamos ante una conducta independiente de la del maltrato injustificado que conllevara lesiones graves anteriormente visto, siendo así un delito de mera actividad que para su consumación bastaría con la acción en si ${ }^{56}$.

Cabe ahora preguntarnos una cuestión importante, y es qué entender por "explotación sexual". Existen autores que, basándose en un símil con la explotación sexual infantil, la definición otorgada por normativa europea de la explotación sexual ${ }^{57}$, e incluso jurisprudencia del Tribunal Supremo ${ }^{58}$, consideran el ánimo de lucro esencial para considerar que exista explotación sexual ${ }^{59}$. Otros autores consideran válida esta interpretación, añadiendo que el aspecto privado de la zoofilia pudiera verse integrada en la conducta de maltrato ${ }^{60}$. Considero al respecto de esta interpretación que pese a poder ser correcta, resulta un tanto

determina que para poder cometerse el delito por comisión por omisión, deberá existir posición de garante del autor respecto al animal. Aplicando la comisión por omisión de este delito se encuentra la SAP de Zaragoza 409/2015, de 10 de febrero, en la que se condena al acusado por haber dejado morirse lentamente de hambre a dos perros que tenía en su casa, encerrados sin comida ni ventilación. La SAP de Madrid 824/2015, de 5 de octubre, también condena por comisión por omisión al propietario de 42 caballos abandonados en una finca de su propiedad, siendo encontrados famélicos y desnutridos tras haberse comido hasta los hierbajos de la finca, llegando incluso a morir de hambre dos de ellos.

${ }^{52}$ REQUEJO, C., El delito de maltrato a los animales tras la reforma del Código Penal por la Ley Orgánica 1/2015, de 30 de marzo en Derecho Animal, 6 (2), (2015), 15, Recuperado de:

https://idus.us.es/bitstream/handle/11441/86277/El\%20delito\%20de\%20maltrato....pdf?sequence=1， consultado 26/02/2020; BRAGE, S., Los delitos, (Valencia, 2017) 80 ss.

${ }^{53}$ BRAGE, S., Idem.

${ }^{54}$ HAVA, E., La protección del bienestar animal a través del Derecho penal en EPCrim, 31, (2011), 299, Recuperado de: https://minerva.usc.es/xmlui/bitstream/handle/10347/7319/261-306.pdf?sequence=1\&isAllowed=y, consultado 27/02/2020.

55 TORRES, M.E., Revisión crítica de los tipos dedicados al maltrato de animales en LLP, 2011, 78, 11.

56 MENÉNDEZ, N., La explotación sexual de animales en Derecho Animal, 6 (2), (2015), 14, Recuperado de: https://revistes.uab.cat/da/article/view/v6-n2-menendez-de-llano/75, consultado 26/02/2020.

${ }^{57}$ Artículo 4 de la Directiva 2011/92/UE.

${ }^{58}$ STS 3111/2011, de 17 de mayo. En ella el TS considera "inherente" el ánimo de lucro con la explotación sexual.

59 MENÉNDEZ, N., La explotación sexual de animales en Derecho Animal, 6 (2), (2015), 11, Recuperado de: https://revistes.uab.cat/da/article/view/v6-n2-menendez-de-llano/75, consultado 26/02/2020.

${ }^{60}$ RIOS, J.M., Comentario en relación al maltrato de animales en la nueva reforma del Código Penal español en Derecho Animal, 6

92 Derecho Animal. Forum of Animal Law Studies, vol. 12/1 
incompleta, pues la zoofilia no podría integrarse en la primera conducta de maltrato a no ser que de la relación sexual mantenida con el animal resultaran unas lesiones graves en el animal.

Por el contrario, existen autores que consideran que no debe mediar ánimo de lucro para que exista explotación sexual, sino un mero abuso o aprovechamiento de la situación de indefensión de la víctima ${ }^{61}$, así como una corriente que defiende lo mismo, pero añadiendo que debe mediar un maltrato injustificado para poder considerar delito a la explotación sexual ${ }^{62}$. Respecto a esta última posición, es defendible siempre y cuando se defienda una interpretación de la norma (analizada en el primer párrafo del epígrafe 3.1.3.) en el que se considere el maltrato injustificado como denominador común de la explotación sexual y de aquel que menoscabe gravemente la salud del animal. Por tanto, debo disentir de esta teoría al haber interpretado la norma de la otra forma anteriormente expuesta en la que la explotación animal se interpreta como una conducta independiente.

Personalmente considero desafortunada la redacción del delito en cuanto al tema que estamos tratando, si bien es un paso hacia adelante respecto a la redacción anterior que no recogía nada sobre el ámbito sexual, resulta bastante confusa. Esto es debido a que, como acabamos de ver, existen diferentes posturas tratando de dar solución a qué debemos entender por explotación sexual en este delito, todas ellas válidas en menor o mayor medida. Considero del mismo modo que tal y como está redactado resulta insuficiente, pues dependiendo de la interpretación que le demos, la zoofilia en sí misma, pese a poder ser cuestionado moralmente, quedaría fuera de la tutela penal al no mediar ánimo de lucro. Como se puede deducir de mis palabras, pese a ser partidario de que la zoofilia esté castigada penalmente, no hay que confundir la situación deseada con la real. Por ello, considero acertada la primera interpretación que defiende la necesidad de que exista ánimo de lucro para que exista explotación sexual, por un simple hecho de coherencia interpretativa en cuanto al término de "explotación sexual", ya que otorgarle diferentes definiciones y significados dependiendo en qué tipo penal o ley se encuentre, vulneraría el principio de seguridad jurídica, en la medida que no se podría prever si una determinada conducta basada en la explotación sexual estaría castigada o no en función del ánimo de lucro y en qué tipo se encuentre. No sería coherente que en un delito tipificado en el CP se exigiera que medie ánimo de lucro para castigar la explotación sexual mientras que en otro para castigar ésta no se exigiera. Al igual que la doctrina, prácticamente unánime, expone que la conducta típica consistente en las lesiones se debe interpretar de la misma forma en la que se interpreta el delito de lesiones hacia las personas, creo lógico que lo mismo debería hacerse en la conducta típica consistente en la explotación sexual.

No obstante, creo conveniente que el legislador en futuras reformas cambie el término "explotación sexual" por "abuso sexual", eximiendo implícitamente de este modo la necesidad de que medie ánimo de lucro para que se pudiera considerar delito esta práctica ${ }^{63}$. De no hacerlo, da pie a situaciones en las que mantener relaciones sexuales con un animal sería impune (siempre y cuando no menoscabe gravemente su salud, de lo contrario podría verse englobada la conducta en la primera modalidad del tipo básico), mientras que, si esas mismas relaciones se mantuvieran a cambio de pagar, por ejemplo, 20 euros a un pastor propietario de una oveja, sí encajaría la conducta en el tipo y sería punible al mediar ánimo de lucro. Al fin y al cabo, estas dos conductas descritas son muy similares, por lo que resulta absurdo que una sea punible y otra no, debido a que se da a entender que lo grave y relevante de la conducta es pagar un precio y no mantener relaciones sexuales con el animal, que a priori debería ser realmente lo relevante. De este modo al cambiar el término "explotación sexual" a "abuso sexual" ambas conductas quedarían englobadas en el tipo. Considero como ejemplo a seguir en este caso la legislación alemana, la cual pena con hasta tres años de prisión los actos sexuales entre animales y personas, incluyendo hasta la difusión de pornografía con animales ${ }^{64}$.

Además, exigir el ánimo de lucro para que la conducta encaje en el tipo, ocasiona que la dificultad probatoria sea máxima, pues, si ya puede resultar muy difícil probar que se han mantenido relaciones sexuales con un animal ${ }^{65}$, más lo sería si además hubiera que probar que ha mediado ánimo de lucro, lo que hace que

(2), (2015), 5, Recuperado de: https://revistes.uab.cat/da/article/view/v6-n2-rios/76, consultado 26/02/2020.

${ }^{61}$ MARQUÉS I BANQUÉ, citado por BRAGE, S., Los delitos, (Valencia, 2017) 83, nota a pie 230.

${ }^{62}$ BRAGE, S., Ibidem, 84.

${ }^{63}$ Como explica MENÉNDEZ, N., La explotación sexual de animales en Derecho Animal, 6 (2), (2015), 16, notas a pie 38 y 39 , Recuperado de: https://revistes.uab.cat/da/article/view/v6-n2-menendez-de-llano/75, consultado 26/02/2020, es una petición que lleva mucho tiempo formulándose por la ciudadanía, llegándose a entregar 200.000 firmas en 2014 para que se tipificara la zoofilia como delito, sumado a las enmiendas formuladas por todos los partidos políticos de la oposición en el Senado en las que se pedía la inclusión del término "abuso sexual" además del de "explotación sexual", aunque al final fueran rechazadas por el Partido Popular, que contaba con mayoría absoluta.

${ }^{64}$ REQUEJO, C., El delito de maltrato a los animales tras la reforma del Código Penal por la Ley Orgánica 1/2015, de 30 de marzo en Derecho Animal, 6 (2), (2015), 14, nota a pie 21, Recuperado de:

https://idus.us.es/bitstream/handle/11441/86277/El\%20delito\%20de\%20maltrato....pdf?sequence=1, consultado 26/02/2020.

65 MENÉNDEZ, N., La explotación sexual de animales en Derecho Animal, 6 (2), (2015), 17, Recuperado de: https://revistes.uab.cat/da/article/view/v6-n2-menendez-de-1lano/75, consultado 26/02/2020 
en la práctica el número de casos condenatorios por este hecho delictivo sea prácticamente inexistente o nulo ${ }^{66}$.

\subsection{Tipo subjetivo}

Primero, hay que ver qué se entiende por dolo. LUZÓN PEÑA ${ }^{67}$ lo define como el conocimiento y voluntad de realizar todos los elementos objetivos del tipo total de injusto. Sería una suma del elemento cognitivo (conocer los datos y circunstancias que fundamentan la antijuricidad, no la antijuricidad en sí misma) y volitivo (voluntad de realizar la conducta típica). Dependiendo de con qué intensidad se manifieste este último elemento, podremos diferenciar entre dolo directo o de primer grado, en el que hay intención inequívoca de realizar el tipo; el dolo de segundo grado, aquel en el que realizar el tipo no es el objetivo principal, pero el autor mediante su conducta sabe que es altamente probable que lo realice, y por tanto lo acepta; y el dolo eventual, en el que la voluntad de realizar el tipo no es muy intensa pero es consciente de la posibilidad de que se realice mediante su conducta, aceptando tal posibilidad.

También existen otras posiciones que entienden que el elemento volitivo no es tan importante, relegándolo a un segundo plano, y dando importancia al elemento cognitivo o más concretamente al conocimiento del riesgo creado para un determinado bien jurídico ${ }^{68}$.

Habiendo analizado el dolo en su esfera teórica, pasemos a analizarlo aplicado en este delito. El delito de maltrato animal es un delito de tipo doloso, no pudiéndose castigar por una mera imprudencia. El CP en su artículo 12 menciona que solamente se podrán castigar las acciones imprudentes cuando así se establezca explícitamente. Al no mencionarse nada sobre la imprudencia en este delito, ha de entenderse que es un tipo exclusivamente doloso. Por tanto, se exige que se cumpla lo descrito en el párrafo anterior. Ello debe entenderse no solo como intencionalidad en hacer sufrir al animal, sino que también es compatible con el tipo otras motivaciones que busque el autor, que pudiendo ser legítimas, dejan de serlo por la manera en la que son realizadas ${ }^{69}$. Un ejemplo de ello sería un vecino que propina una patada a un perro para que deje de orinar cerca de su puerta, o aquel que dispara balines a unos gatos callejeros para que no entren en su propiedad. En este primer ejemplo, el autor no tiene en principio dolo de primer grado, pues su intención es simplemente mantener su puerta alejada de orines de perro, no maltratar al animal, aunque por ello no deja de ser una conducta penalmente punible. En este delito no solo sería castigable una conducta dolosa de primer grado, sino que también se castigarían las conductas dolosas de segundo grado y de dolo eventual. Así, bastaría con una intención mínima de realizar el tipo (dolo eventual) para que fuera punible dicha acción. Cabe aclarar esto ya que, en versiones anteriores del CP de 2010, se exigía que la conducta típica fuera con ensañamiento, lo que parte de la doctrina entendía como que debía existir dolo directo, no pudiéndose castigar aquella conducta realizada con dolo eventual ni dolo de segundo grado ${ }^{70}$. Muestra de ello es la jurisprudencia existente anterior a 2010, donde en algunas ocasiones se acordaba la absolución del acusado por no mediar dolo directo o de primer grado. Así, un caso de una persona que mata de tres disparos de escopeta al perro de un vecino que se colaba en su finca, no fue considerado como falta de maltrato animal ya que "su finalidad es darle muerte para que no le moleste, no quiere causarle un sufrimiento sino eliminar un problema para él."

Desde la reforma de 2010 la exigencia de que la conducta se realizara con ensañamiento se suprimió, por lo que, desde entonces, es totalmente válida y nada problemática la acción realizada con cualquier tipo de dolo para cumplir con el tipo, ya sea de primer o segundo grado o dolo eventual.

Pese a que ya no existe problema a la hora de determinar qué tipo de dolo existe en la conducta del acusado, pues pasa a ser irrelevante al castigarse toda conducta independientemente del dolo que sea, existen problemas en este delito a la hora de determinar si una conducta es dolosa (punible) o imprudente (no punible). Como ejemplo, podemos mencionar el caso tan mediático ocurrido en Cáceres en $2018^{72}$, cuyo vídeo se propagó por redes sociales y noticiarios, en el que un cazador acorrala con sus perros a un ciervo al borde de un barranco, por el que se acaban despeñando 12 perros y el propio ciervo, quedando uno de los perros gravemente herido y otro muerto. Pese a la claridad de las imágenes en las que, incluso siendo advertido por las personas que grababan el vídeo, se ve al cazador actuando con total indiferencia y desprecio hacia la vida

\footnotetext{
${ }^{66}$ En este sentido, REQUEJO, C., El delito de maltrato a los animales tras la reforma del Código Penal por la Ley Orgánica 1/2015, de 30 de marzo en Derecho Animal, 6 (2), (2015), 14, nota a pie 21, recuperado de: https://idus.us.es/bitstream/handle/11441/86277/El\%20delito\%20de\%20maltrato....pdf?sequence=1, consultado 26/02/2020, expresa que si se exige que haya ánimo de lucro se ocasiona que estas conductas queden totalmente impunes.

${ }^{67}$ LUZÓN, D.M., Lecciones, (Valencia, 2016) 228, 16/32; 230, 16/36; 231, 16/40.

${ }^{68}$ STS 2243/2014, de 21 de mayo.

${ }^{69}$ CUERDA, M.L., citado por BRAGE, S., Los delitos, (Valencia, 2017) 85, nota a pie 240.

${ }^{70}$ BRAGE, S., Ibidem, 86, nota a pie 242.

${ }^{71}$ SAP Madrid 5431/2004 de 19 de abril.

72 (Vídeo en línea): https://www.lasexta.com/noticias/sociedad/durisimas-imagenes-de-como-12-perros-se-despenan-por-unbarranco-ante-la-irresponsabilidad-de-un-cazador-video_201811185bf15cc20cf2265d3004c92f.html, consultado 01/03/2020.

94 Derecho Animal. Forum of Animal Law Studies, vol. 12/1
} 
de sus propios animales, el juez estimó mediante auto que esta persona actuó con imprudencia y no con dolo, acordando el sobreseimiento provisional al no poder castigarse penalmente esta conducta supuestamente no dolosa $^{73}$.

En este auto en concreto, el juez considera en su fundamento jurídico cuarto que la conducta no se ajusta al tipo al no existir dolo, ya que el acusado no ha golpeado a los perros directamente. Una decisión como mínimo cuestionable, por no decir totalmente errónea e infundada, ya que el juez hace una lectura e interpretación absolutamente equívoca del tipo, confundiendo el dolo con el golpear directamente a los animales, obviando que el tipo menciona expresamente que el maltrato se puede realizar "por cualquier procedimiento", no teniendo que ser necesariamente dando golpes al animal, e ignorando del mismo modo que es un delito que se puede cometer con dolo eventual, que es en efecto el que se aprecia en este caso. Además, como hemos visto anteriormente, es un delito que no tiene que ser cometido necesariamente de propia mano, es decir, no es siquiera necesario que fuera el acusado quien empujara a sus animales al barranco, y mucho menos que los golpee, bastando con el simple hecho de que les azuzara propiciando que se precipiten por él.

Para poder diferenciar entre una conducta dolosa eventual (que es la que se defiende que existe en este caso) y una imprudente, es necesario para que sea dolo eventual que el sujeto acepte o consienta la eventual producción del hecho, pudiéndose considerar imprudencia en el caso de que existan bastantes posibilidades objetivas de que no se produzca el hecho ${ }^{74}$. Pues bien, en este caso, de la actitud y conducta del acusado se desprende que, en efecto, acepta la producción del hecho, ya que no hace absolutamente nada para impedir que sus perros se despeñen, actuando con absoluta parsimonia incluso cuando es advertido por los demás presentes, sumado al hecho de que sus perros están literalmente en el borde del precipicio, lo que indica que las posibilidades objetivas de que se produzca el hecho son ciertamente altas. De la misma forma, tampoco parece preocuparle cuando de hecho sus animales empiezan a despeñarse por el barranco uno tras otro. Al haber sido él quién ordenara a sus perros aproximarse a ese lugar con riesgo altísimo de que se precipitaran, y a deducir de su conducta observable, no se puede sino afirmar que actúa con dolo eventual, ajustándose su conducta al tipo y cometiendo por tanto el hecho delictivo. Es más, aun suponiendo que él no ha sido quien azuzara a los animales para que acorralaran al ciervo al borde del precipicio, se podría discutir la posibilidad de que cometiera el delito mediante comisión por omisión, visto anteriormente, por encontrarse él en posición de garante respecto a sus perros y ni siquiera tratar de impedir la ocurrencia de estos hechos.

La problemática de discernir entre dolo eventual e imprudencia se palpa en muchos otros casos. Por ejemplo, se acordó la absolución del acusado recurrente ${ }^{75}$ tras estimar que no concurría dolo eventual, sino una mera imprudencia, en el caso de un hombre que atropella a un gato que se encontraba en el motor de su vehículo. El autor en este caso es advertido por una vecina mediante una nota en el cristal, la cual vio cómo treinta minutos antes de que cogiera él el coche un gato se introdujo en el interior de éste por la parte de abajo. Tras leer la nota, el autor, junto con esta vecina, estuvo 10 minutos tratando de abrir el capó, sin escuchar ningún ruido en el interior de éste que pudiera hacerles pensar que el gato siguiera dentro. Tras este periodo de tiempo, el autor arrancó el motor del coche y se dispuso a conducir hacia su puesto de trabajo, pero desafortunadamente el gato, que se encontraba todavía dentro pese a haber examinado el coche, cayó al suelo y fue atropellado por la rueda trasera, muriendo en consecuencia. A diferencia del caso anterior, concuerdo totalmente en la decisión del tribunal, ya que no se puede apreciar dolo de ningún tipo respecto de su conducta, en la que, tras haber examinado el coche para intentar evitar la posible producción del hecho, deduce que no existe riesgo en conducirlo al entender que el gato ya se había marchado, percibiendo entonces objetivamente imposible la producción del hecho. Por todo ello no se puede apreciar que concurra dolo en su conducta, sino imprudencia en todo caso, por lo que no puede ser objeto de castigo penal al no estar contemplada la conducta imprudente como punible.

Cabe añadir que la doctrina es partidaria de considerar que existe dolo en conductas que en un principio son imprudentes, al haber antecedentes en el autor de hechos similares en los que medie imprudencia. Así, una persona que se olvida a su perro en el coche en verano, ocasionándole graves lesiones físicas o incluso la muerte, se podría considerar una conducta imprudente. Pero si esa conducta la lleva a cabo más veces, se consideraría entonces como dolosa y por tanto punible ${ }^{76}$.

\footnotetext{
${ }^{73}$ Dictado por el auto del Juzgado de Primera Instancia e Instrucción núm. 1 de Valencia de Alcántara el 21 de junio de 2019 , Recuperado de: http://aranzadi.aranzadidigital.es/maf/app/document?tid=\&docguid=I6637e1409d3011e9be29010000000000\&baseguids=JUR $\backslash 2019 \backslash 196439 \&$ fexid=flag-red-juris\&fexid=flag-yellow-juris\&fexid=flag-blue-juris\&fexid=DO-ANA-25\&fexid=DOANA-23\&srguid=i0ad82d9a000001709b42d9462d2a82c0\&src=withinResuts\&spos=1\&epos=1 consultado 02/03/2020.

${ }^{74}$ LUZÓN, D.M., Lecciones, (Valencia, 2016) 241, 16/79.

75 SAP Las Palmas 10/2019 de 14 enero.

${ }^{76}$ BLANCO, I., Comentarios, IV, (Navarra, 2015) 185.
} 


\section{Iter criminis}

El delito en su modalidad de "maltrato injustificado que menoscabe gravemente la salud del animal", al ser un delito de resultado, se puede apreciar su comisión en grado de tentativa, causando mediante maltrato injustificado lesiones leves que no lleguen al resultado de causar las lesiones graves exigidas por el tipo ${ }^{77}$.

Por el contrario, existen autores que no consideran la posibilidad de cometer el delito en grado de tentativa al existir el tipo atenuado contemplado en el apartado 4 del artículo $337 \mathrm{CP}$, al no exigir éste un resultado de lesiones graves y considerar el resultado de lesiones graves del tipo básico no como resultado sino como una condición objetiva de punibilidad ${ }^{78}$.

Considero acertada la primera postura, pues pese a no conseguir el resultado de menoscabar con lesiones graves la salud del animal, en muchos casos se puede apreciar tal intencionalidad pese a no lograr el resultado perseguido. Por ejemplo ${ }^{79}$, sería punible por tentativa del delito contemplado en el tipo básico el dejar encerrado a un animal sin comida ni agua con la intención de dejarlo morir de inanición, pero no llegándose a producir por la intervención de terceros que consiguen liberar al animal.

Si se tomara como válida la postura que considera la no aplicación del grado de tentativa en el tipo básico en beneficio de la aplicación del tipo atenuado, se estaría excluyendo la tutela penal en determinados casos a algunos animales dependiendo de en qué circunstancia se dé este maltrato, ya que el tipo atenuado y el tipo básico no contemplan a los sujetos pasivos de la misma forma, lo cual estudiaremos en profundidad más adelante. En un ejemplo ilustrativo donde se entienda mejor, si un entrenador de animales para un circo, enseñara, por ejemplo, a los monos a base de descargas eléctricas y fuertes golpes, no encajaría en el tipo básico en la medida en la que no resulten graves lesiones en la salud del animal, mientras que tampoco encajaría en el tipo atenuado al no tratarse de un animal doméstico ni de perpetrarse el maltrato en un espectáculo, ya que se estaría realizando a parte de éste, en un simple entrenamiento. Para poder castigar penalmente esta conducta, es necesario contemplar la comisión del tipo básico en grado de tentativa. Que en la última reforma del CP se hayan incluido nuevos grupos de animales (en este ejemplo sería el mono) parece que el legislador trata de otorgarle una protección que, en algunos casos concretos como el que acabamos de ver de no aceptar la comisión en grado de tentativa del tipo básico, se la estaríamos arrebatando al no poder aplicarse el tipo atenuado al no encajar esta conducta en él.

Si bien es cierto que no se puede castigar del mismo modo un delito consumado que otro en grado de tentativa, eso no elimina la punibilidad de esta última modalidad. Por lo tanto, considero coherente la posibilidad de contemplar la comisión en grado de tentativa de este delito, ya que como hemos visto, habrá tentativas del tipo básico que no puedan encajarse en el tipo atenuado.

En la segunda modalidad del delito, la de explotar sexualmente al animal, se considera como se ha defendido anteriormente que es un delito de mera actividad, consumándose con la propia acción ${ }^{80}$. Pese a lo explícito del ejemplo, podría llegar a apreciarse tentativa en el caso de una persona que justo antes de disponerse a mantener relaciones sexuales con un animal (habiendo ánimo de lucro), fuera pillado in fraganti y frenado en su intento, tratándose entonces de una tentativa inacabada. No deja de ser un ejemplo de un caso ficticio muy concreto, por lo que lo normal será apreciar este delito consumado en su totalidad.

\section{Causas de justificación}

Como se ha venido adelantando anteriormente, pero sin haber entrado demasiado en materia, el tipo recoge expresamente el término "injustificadamente", por lo que veremos a continuación qué conductas son justificadas y por tanto quedan excluidas del tipo, así como las causas de justificación genéricas aplicables a este delito.

Con este término lo que se pretende es excluir determinadas conductas que encajarían, en principio, en el tipo, pero que mediante normativa estatal o autonómica quedan fuera de él, ya que son socialmente $\operatorname{aceptados}^{81}$. Del mismo modo se pronuncia la SAP de Las Palmas 10/2019 de 14 enero, en la que se dice que

\footnotetext{
${ }^{77}$ REQUEJO, C., La protección penal, (Granada, 2010) 56 ss.

${ }^{78}$ MUÑOZ, J., LLP, (2007), 42, 23. El autor hace referencia al tipo atenuado del art. 632.2 del CP de aquel entonces, que es igual al tipo atenuado del art. 337.4 del CP actual.

${ }^{79}$ Propuesto por BRAGE, S., Ibidem, 87.

${ }^{80}$ En contra, BRAGE, S., Los delitos, (Valencia, 2017) 87, establece a consecuencia de la interpretación que otorga a la explotación sexual que para consumarse el delito debe existir un sufrimiento injustificado e innecesario, ya que considera que debe mediar un maltrato injustificado también en la explotación sexual. De este modo podría apreciarse tentativa cuando exista explotación sexual pero el animal no sufra a consecuencia de ello; A favor, MENÉNDEZ, N., La explotación sexual de animales en Derecho Animal, 6 (2), (2015), 14, el cual también interpreta dos conductas típicas diferenciadas, entendiendo un delito de actividad la explotación sexual, consumándose con la propia acción.

${ }^{81}$ HAVA, E., La protección del bienestar animal a través del Derecho penal en EPCrim, 31, (2011), 300 ss, Recuperado de:

96 Derecho Animal. Forum of Animal Law Studies, vol. 12/1
} 
el legislador "busca excluir del tipo conductas que se encuentren legalmente permitidas y/o autorizadas". De esta manera estas conductas "justificadas" quedarían excluidas del tipo, excluyendo así la antijuricidad material, entendida esta como "la lesión o puesta en peligro reprochable y grave de un bien jurídico protegido", ya que, aunque esta lesión tiene lugar, da lugar a una colisión de intereses que se resuelve mediante una ponderación de éstos, que hace que no resulte desvalorada y se autorice esta conducta ${ }^{82}$.

Todas estas circunstancias establecidas por normativa que excluyen a la conducta del tipo al considerarse justificadas, se pueden englobar en la causa de justificación de ejercicio legítimo de un derecho recogido en el artículo $20.7 \mathrm{CP}^{83}$, la cual se debe orientar siempre por los principios de necesidad y proporcionalidad $^{84}$.

No se trata de una norma penal en blanco, pues, aunque tengamos que apoyarnos en otra normativa para ver qué está justificado, no se trata de una remisión en bloque a otra norma, sino que existe una remisión interpretativa al término "injustificadamente". De esta manera se trataría de una ley con elementos normativos del tipo, ya que para la comprensión de su alcance se necesita de otra norma (incluso de menor rango), pero la conducta típica y el núcleo esencial de la prohibición ya están recogidos en la propia configuración del delito, a diferencia de la ley penal en blanco, que remitiría a otra norma para que ésta estableciera el elemento típico ${ }^{85}$.

Existen autores que creen que haber integrado el término "injustificadamente" en el tipo sobra y es del todo inútil, ya que existen las causas de justificación del artículo $20 \mathrm{CP}$ que son perfectamente aplicables en este delito ${ }^{86}$. Coincido totalmente con esta idea, añadiendo que es totalmente redundante exigir que la conducta sea injustificada, ya que de estar justificada la acción (tanto en este delito como en cualquier otro que no se exija expresamente la "injustificación") no sería penalmente punible. Sería algo parecido a haber tipificado el delito exigiendo expresamente que por ejemplo no se incurra en ningún error de tipo o de prohibición invencible para que sea punible. Es algo obvio y que ocurre con cualquier delito, por lo que creo que resulta prescindible a la hora de tipificarlo.

Analizado esto, nos detendremos a analizar la normativa más relevante que permite justificar alguna conducta contemplada en el tipo bajo el pretexto del ejercicio legítimo de un derecho.

\subsection{Ejercicio legítimo de un derecho 6.1.1. Experimentación científica}

En primer lugar, existen normas sobre la experimentación científica con animales. La legislación europea promulga el principio de "las tres erres" ${ }^{87}$, determinándose mediante éste que se deberá reemplazar el uso de animales por otras técnicas satisfactorias que no requieran de estos, reducir el número de animales en caso de tener que usarlos, y el refinamiento, es decir, eliminar en la medida de lo posible el dolor y daños utilizando anestesia.

Este principio se recoge en el artículo 1 y 4 de la Directiva 2010/63, relativa a la protección de los animales utilizados para fines científicos. También se recogen en los artículos 6,7 y 8 del Convenio Europeo de 18 de marzo de 1986 sobre protección de los animales vertebrados utilizados con fines experimentales y otros fines científicos, ratificado por España en 1989, donde también se determina que solamente se podrán usar animales en procedimientos científicos, resumidamente, cuando se trate de prevenir enfermedades, diagnosticar o tratar enfermedades, detectar o evaluar condiciones fisiológicas en los seres vivos, proteger el medio ambiente, investigación científica, educar y formar, e investigaciones forenses. En cuanto a legislación estatal, disponemos del Real decreto 53/2013, de 1 de febrero, por el que se establecen las normas básicas aplicables para la protección de los animales utilizados en experimentación y otros fines científicos, incluyendo la docencia.

Pese a que es un número elevado de supuestos en los que se permite usar a animales y que alguno de ellos es extremadamente genérico, como por ejemplo el de "investigación científica", gracias a esta normativa la utilización de animales en la elaboración de cosméticos o productos químicos en general está totalmente prohibida. Además, en virtud de la Directiva antes mencionada, se establecen diversas prohibiciones como

\footnotetext{
https://minerva.usc.es/xmlui/bitstream/handle/10347/7319/261-306.pdf?sequence=1\&isAllowed=y, consultado 27/02/2020.

82 LUZÓN, D.M., Lecciones, (Valencia, 2016) 167, 13/10.

${ }^{83}$ BRAGE, S., Los delitos, (Valencia, 2017) 78.

${ }^{84}$ BLANCO, I., Comentarios, IV, (Navarra, 2015) 182.

${ }^{85}$ LUZÓN, D.M., Lecciones, (Valencia, 2016) 61, 5/50 y 185 14/20 ss.

${ }^{86}$ GARCÍA, M., El delito de maltrato a los animales. El maltrato legislativo a su protección, en Revista de Bioética y Derecho, (2015), 50, recuperado de: https://www.redalyc.org/pdf/783/78343122008.pdf, consultado 13/02/2020.

87 JIMENA, A., Experimentación animal, El independiente, 04/06/2017, Recuperado de:

https://www.elindependiente.com/futuro/2017/06/04/experimentacion-animal-los-cientificos-somos-los-primeros-que-queremosevitarla/, consultado 15/03/2020.
} 
investigar con primates no humanos salvo en ocasiones muy especiales y concretas ni con animales capturados en la naturaleza.

Para que esta conducta quede "justificada" y excluida del tipo, además de utilizarse los animales con los propósitos establecidos, deberán cumplirse los requisitos establecidos en todos los demás artículos, sobre todo los referidos a reducir el sufrimiento, pues de lo contrario, sí podría ser constitutiva de delito de maltrato animal pese a tratarse de una investigación en principio legítima.

\subsubsection{Consumo}

En segundo lugar, existe numerosa normativa ${ }^{88}$ en cuanto a la utilización de animales para consumo, destacando en el ámbito estatal la Ley 32/2007, de 7 de noviembre, para el cuidado de los animales, en su explotación, transporte, experimentación y sacrificio, estableciéndose requisitos tales como transportar a los animales en condiciones que no les causen lesiones, manipularlos sin causarles temor ni dolor, así como sacrificarlos evitando agitación, dolor o sufrimiento innecesarios. El Real Decreto 37/2014, de 24 de enero, por el que se regulan aspectos relativos a la protección de los animales en el momento de la matanza, establece por su parte que se debe aturdir a los animales antes de perpetrar la matanza, como también establece el Reglamento CE 1099/2009 de 24 de septiembre de 2009 relativo a la protección de los animales en el momento de la matanza.

De este modo y como en el ejemplo anterior, esta actividad quedaría excluida del tipo cuando se cumplan todos los requisitos legalmente establecidos.

Se pueden observar numerosos casos en los que determinados hechos pueden ser constitutivos de delito en explotaciones ganaderas. Esto es debido a que, una conducta en principio excluida del tipo como es la de matar animales en una explotación ganadera, deben siempre cumplir esas condiciones mínimas ya mencionadas a la hora de matar a los animales, o de lo contrario esa conducta "volvería a entrar" en el tipo. Por ejemplo, no son pocos los casos en los que los requisitos de aturdimiento antes de matar al animal y manipularlos sin causarles temor o dolor se pasan totalmente por alto en determinados mataderos. Este es el caso de un matadero de Albacete, en el que se mata a un caballo sin aturdirlo antes, dejándolo agonizar durante minutos $^{89}$, incumpliendo así la normativa aplicable y por tanto pudiendo cometer un delito de maltrato animal. Por otra parte, también son incontables los casos en los que el responsable de una explotación ganadera descuida por completo las condiciones higiénico-sanitarias de sus instalaciones y animales ${ }^{90}$, por lo que mueren debido a ello, siendo esta también una conducta constitutiva de delito por comisión por omisión como hemos estudiado anteriormente.

\subsubsection{Sacrificios religiosos}

Por otro lado, tenemos normativa que permite el sacrificio de animales en el ámbito religioso. En estos casos, tanto en la religión judía como musulmana, se realiza una práctica consistente en degollar a una cabra sin aturdirla previamente ni aplicarle ningún tipo de anestesia. Pese a ser una conducta que encaja en el tipo, el anteriormente citado Reglamento CE 1099/2009 y la Ley 32/2007, permiten este tipo de sacrificios siempre que se realice en un matadero y se comunique a la autoridad para registrarlo a tal efecto, siguiendo las órdenes de un veterinario oficial y siempre que esa confesión religiosa esté registrada en el Registro de Entidades Religiosas. Además, existe doctrina que defiende que, de prohibir este tipo de sacrificios, se estaría vulnerando el derecho fundamental de la libertad religiosa, reconociéndose así incluso por jurisprudencia del Tribunal Europeo de Derechos Humanos ${ }^{91}$.

\subsubsection{Tauromaquia}

También existe, por supuesto, normativa referida a la tan polémica tauromaquia, ya que el toro bravo entra dentro de los sujetos pasivos descritos por el tipo como hemos visto anteriormente. Así, existe la Ley 18/2013, de 12 de noviembre, para la regulación de la Tauromaquia como patrimonio cultural, como la Ley

\footnotetext{
${ }^{88}$ En cuanto a normas europeas para salvaguardar el bienestar de diferentes grupos de animales como terneros, cerdos o gallinas, existen, entre otras: Directiva 93/119/CE, Directiva 98/58/CE, Directiva 99/74/CE, Directiva 2008/119/CE, Directiva 2008/120/CE. ${ }^{89}$ ELCACHO, J., Matadero inhumano, La Vanguardia, 10/12/2019, Recuperado de:

https:/www.lavanguardia.com/natural/20191210/472161697537/dia-internacional-derechos-animales-video-denuncia-maltratomatadero-albacete-equalia.html, consultado 9/03/2020.

${ }^{90}$ Investigados, Agrodigital, 20/02/2020, Recuperado de https://www.agrodigital.com/2020/02/20/360579/ consultado 9/03/2020. Detenido, Agroinformación, 14/09/2019, Recuperado de: https://agroinformacion.com/detenido-un-ganadero-de-26-anos-de-saguntopor-un-delito-de-maltrato-animal-de-11-bovinos-y-un-caballo/, consultado 9/03/2020.

${ }^{91}$ BRAGE, S., Los delitos, (Valencia, 2017) 78, nota a pie 212.

98 Derecho Animal. Forum of Animal Law Studies, vol. 12/1
} 
10/2015, de 26 de mayo, para la salvaguardia del Patrimonio Cultural Inmaterial, que establecen la tauromaquia como patrimonio cultural digno de protección en todo el territorio nacional, siendo deber de los poderes públicos su conservación. Por ello, ya que existe normativa que otorga especial protección a este espectáculo, se puede entender justificada esta conducta, consistente en menoscabar gravemente la salud del toro para después ejecutarlo. Hay que mencionar del mismo modo que la Directiva 98/58/CE relativa a la protección de los animales en las explotaciones ganaderas, excluye de su ámbito de aplicación a los animales destinados a participar en actividades culturales. Es mencionable la explicación de Vytenis Andriukaitis, comisario europeo de Salud y Seguridad Alimentaria, en respuesta a una pregunta parlamentaria ${ }^{92}$ en la que se pedía aclaración sobre si estos malos tratos ejercidos sobre los animales destinados a morir en espectáculos eran justificados solamente en el momento del espectáculo en sí, o si se debía de extender a los momentos anteriores en los que el animal se encontraba en la explotación ganadera, así como en su transporte y demás circunstancias. El comisario expone que, en efecto, se debe interpretar la norma de manera que estos animales quedan excluidos de su ámbito de aplicación en todo momento, no debiéndose considerar entonces como maltrato conductas tales como un transporte del animal en pésimas condiciones, o la tienta ${ }^{93}$ de becerros, por ejemplo. En la misma línea se encuentra la Ley 32/2007, de 7 de noviembre, para el cuidado de los animales, en su explotación, transporte, experimentación y sacrificio, anteriormente vista, excluyendo de su ámbito de aplicación a los espectáculos taurinos. Con el CP anterior a la reforma del 2015 existía menos problemática sobre si la tauromaquia podía entrar en el tipo, ya que el toro de lidia o toro bravo no se consideraba ni doméstico ni amansado ${ }^{94}$ (animales que son sujeto pasivo del delito), por lo que ni siquiera encajaría en el tipo el maltrato hacia este animal, no siendo necesaria por aquel entonces ninguna ley que otorgara de protección a la tauromaquia, ni siendo necesario justificarla, por tanto.

Habiendo analizado esto, cabe preguntarnos, por otro lado, si una determinada conducta puede ser constitutiva de delito dependiendo del lugar donde nos encontremos, al depender el término "injustificadamente" en ocasiones de legislación autonómica, siendo esta la que excluya o no la conducta del tipo. En efecto, existen casos donde la regulación autonómica ampara unas conductas que en otras comunidades serían objeto de delito. Por ejemplo, la Ley canaria 8/1991, de 30 de abril, de protección de los animales, permitiría las peleas de gallos en las localidades donde tradicionalmente se venían practicando, con la condición de no dejar pasar a los menores de 16 años. Este, como se puede ver, es un claro ejemplo donde una conducta es delito en un lugar y no en otro al estar justificada por normativa autonómica ${ }^{95}$. Es destacable en este aspecto el caso de Cataluña, la cual prohibió la tauromaquia en casi todas sus modalidades en $2010^{96}$, aunque se declaró inconstitucional esta medida por parte del Tribunal Constitucional tras un recurso de inconstitucionalidad de los senadores del Partido Popular, ya que entendían que no tenía competencia la Comunidad Autónoma para prohibirlo.

$\mathrm{Al}$ respecto, existe jurisprudencia que nos viene a decir que esta diferencia de criterio a la hora de determinar si una conducta es constitutiva de delito o no en función del territorio no vulnera el artículo 14 de la Constitución, ya que es consecuencia de la distribución territorial del Estado y las competencias transferidas a las Comunidades Autónomas ${ }^{97}$.

En cuanto al hecho defendido por la doctrina de que la causa de justificación "ejercicio legítimo de un derecho" se oriente por los principios de necesidad y proporcionalidad, no podemos evitar preguntarnos si determinados derechos de las personas atienden a estos criterios a la hora de ver justificada una conducta que encaja en el tipo. Personalmente, creo que determinadas conductas vistas como el consumo de carne o la investigación con animales en casos que no sea posible investigar sin ellos, cumplirían sin ningún género de dudas estos principios. Si bien es cuanto menos discutible que la celebración de un festejo en donde se mata a un animal por mero entretenimiento (aunque este entretenimiento se lleve realizando durante buena parte de nuestra historia) cumpla los principios de necesidad y proporcionalidad para que tal conducta se vea justificada. ¿Es igual de necesario alimentarnos que ver por mero placer cómo se da muerte a un animal en la arena? ¿Es igual de proporcionado menoscabar la salud de los animales en busca de una cura de una grave enfermedad que hacerlo por "amor al arte"? Estoy hablando por supuesto de la tauromaquia, y pese a que en el plano legal no existen dudas de que esta conducta está justificada por la legislación anteriormente vista que lo ampara, creo necesario un ejercicio crítico de reflexión donde nos planteemos como sociedad modificar

\footnotetext{
92 Respuesta del Sr. Andriukaitis en nombre de la Comisión, 11 de enero de 2016, Recuperado de: https://www.europarl.europa.eu/doceo/document/E-8-2015-014419-ASW_ES.html, consultado 10/03/2020.

${ }_{93}$ La tienta es una técnica consistente en golpear con una pica al becerro o becerra estando montado a caballo, para determinar la "bravura" del ejemplar.

${ }^{94}$ BLANCO, I., Comentarios, 2010, 1316, Recuperado de: https://acortar.link/152m, consultado 15/03/2020.

${ }^{95}$ BRAGE, S., Los delitos, (Valencia, 2017) 106.

${ }^{96}$ Mediante la Ley 28/2010, de 3 de agosto, de modificación del artículo 6 del texto refundido de la Ley de protección de los animales, aprobado por el Decreto legislativo 2/2008, no prohibiendo el festejo del correbous, festejo taurino tradicional en Cataluña.

${ }^{97}$ BRAGE, S., Los delitos, (Valencia, 2017) 108.
} 
estas leyes y costumbres, evitando el sufrimiento agónico de un animal con el único propósito del disfrute humano. Todo esto no deja de ser un simple debate ético o social y no de carácter legal, que al fin y al cabo es lo que se trata de analizar en este trabajo, pero no tenemos por ello que dejar de tenerlo en cuenta, pues como bien sabemos, el Derecho es un reflejo de la sociedad, recogiendo los cambios que suceden y avanzando $\mathrm{y}$ evolucionando con ella. Al respecto, existen incontables encuestas ${ }^{98}$ a la población española en las que se refleja que la mayoría de los españoles están en contra de la tauromaquia, queriendo limitarla o directamente prohibirla. Esto nos hace pensar que, tarde o temprano, el Derecho mediante modificaciones legislativas dejará de considerar a estos espectáculos como dignos de ser un caso amparado por una causa de justificación y por tanto excluyentes de la antijuricidad, pasando simplemente a ser una modalidad más de maltrato animal.

\subsection{Estado de necesidad}

Tras haber visto estas causas de justificación englobadas en el ejercicio legítimo de un derecho, también puede concurrir la causa de justificación de estado de necesidad defensivo, recogida en el artículo $20.5 \mathrm{CP}$, en el que se viera justificada una agresión a un animal para defenderse ${ }^{99}$. Por ejemplo, hubo un caso en el que un toro se escapó de un festejo taurino en Vidreres en el año 2019, ocasionando unos 20 heridos, dos de ellos muy graves, por lo que un policía local tuvo que abatirlo de un disparo ${ }^{100}$. En este caso es indiscutible que concurren todos los requisitos del estado de necesidad, ya que se pretende evitar la muerte de cualquier persona mediante la muerte del animal, ya que la vida humana tiene mayor valor que la vida del animal y la situación de necesidad no fue provocada por el sujeto. De este modo se cumplen los requisitos de proporcionalidad, idoneidad, el peligro de un bien jurídico, así como la necesidad del medio empleado, ya que, aunque pudiesen existir medios menos lesivos como puede ser la sedación del animal, es evidente que el policía no disponía de tales medios en aquel momento.

Otro ejemplo de la aplicación del estado de necesidad lo encontramos en la SAP de Valencia 530/2010, de 1 de septiembre que, aunque se basa en la versión del CP anterior a la vigente, el juez entiende que no se puede condenar al acusado por no ser penalmente reprochable su conducta al tratarse de una conducta defensiva (si bien no justifica de ninguna manera si se trata de un estado de necesidad o si concurren sus requisitos). Los hechos de este caso son los siguientes: el denunciante llega a su casa, y al abrir la puerta sale su perro, quien se dirige a casa de su vecino junto con otros perros que estaban en las inmediaciones de ambas casas, ya que la perra de este vecino tenía el celo. La puerta de la casa del vecino se encontraba abierta por lo que los perros entran, dirigiéndose a la estancia donde están la perra en celo, el acusado y su sobrina de corta edad jugando. Al ver que los perros entran, el acusado propina una fuerte patada al perro del denunciante, causándole la muerte. Se justifica su acción en la sentencia debido a que es "defensiva" respecto a su sobrina, si bien no se acredita que los perros fueran un peligro real para la niña, teniendo en cuenta que el medio empleado para impedir la entrada a los perros es cuanto menos excesivo e innecesario, pudiendo ser perfectamente dolosa la conducta, ya que hubiera bastado algún empujón o incluso un grito para que los animales no entraran en su casa, siendo incluso reprochable la provocación imprudente del suceso, dejando la puerta abierta de su casa habiendo perros en las inmediaciones y teniendo él una perra en celo. Por todo ello y pese a que en la sentencia se acuerda la absolución del acusado, no aprecio que exista un estado de necesidad que así lo justifique.

Un caso muy mediático fue el del perro Excalibur ${ }^{101}$, que fue sacrificado en el año 2014, ya que su dueña tenía el ébola y existía muy poca información científica sobre cómo podían padecer la enfermedad los animales y, sobre todo, cómo podían transmitirla, ya que no se podía asegurar que los animales no eliminaran el virus a través de sus fluidos y heces. Por ello, se dictó una resolución de la Consejería de Sanidad ratificada mediante resolución judicial en la que se acordaba el sacrificio del animal, ocasionando un gran rechazo e incluso organizándose manifestaciones en contra. No cabe duda de que con esta medida se trató de evitar la propagación de un virus que alcanzaba hasta el $90 \%$ de mortalidad ${ }^{102}$, entrando en conflicto la vida del animal

\footnotetext{
98 SERRA, J.M., Cerca del $60 \%$ de los españoles se oponen a la tauromaquia, La Vanguardia, 26/01/2016, Recuperado de: https://www.lavanguardia.com/vida/20160122/301601192081/espanoles-contra-toros.html, consultado 11/03/2020; MADUEÑO, J.D., Más de la mitad quiere "limitar o prohibir" los toros y la caza, El Español, 12/01/2019, Recuperado de: https://www.elespanol.com/espana/20190112/mitad-quiere-limitar-prohibir-toros-caza/367963207_0.html, consultado 11/03/2020. Cabe destacar que estas encuestas son incluso publicadas por periódicos con una línea editorial taurina.

${ }^{99}$ BRAGE, S., Los delitos de maltrato y abandono de animales, (Valencia, 2017) 78 ss.

100 Una veintena de heridos al escapar un toro, La Vanguardia, 01/09/2019, Recuperado de https://www.lavanguardia.com/local/girona/20190901/47124307594/toro-escapa-correbou-vidreres-girona-heridos-gravecritico.html, consultado 10/03/2020.

${ }^{101}$ Excalibur ha sido sacrificado, El Mundo, 09/10/2014, Recuperado de: https://www.elmundo.es/espana/2014/10/08/5434f0eee2704e173e8b456f.html, consultado 12/03/2020.

102 Preguntas frecuentes sobre la enfermedad por el virus del Ébola, Comunicado de la OMS, mayo 2017, Recuperado de: https://www.who.int/csr/disease/ebola/faq-ebola/es/, consultado 12/03/2020.
} 
con una posible crisis de salud pública en el país, en el que claramente tiene un mayor valor el segundo bien jurídico protegido. Si bien podría encajar en el estado de necesidad, cabe preguntarse si fue totalmente necesario el medio concreto empleado, o si por el contrario hubiera bastado mantenerle en cuarentena a la espera de su evolución. Personalmente, creo oportuna la medida que se llevó a cabo, ya que como se ha dicho, no se conocían todos los datos del virus en los animales, sin saber si esa medida hubiera sido efectiva o si existía posibilidad de salvar al perro del virus en caso de ser portador de él, o mucho más importante, si se podía asegurar que el perro no contagiara a nadie, ya que se desconocía como traspasaban el virus los animales. Mantenerlo en cuarentena hubiera sido una medida menos lesiva, sin duda. Pero ésta no podía asegurar totalmente el resultado perseguido, que era no propagar el virus. Por ello, considero que el medio elegido fue el adecuado pues era el único que podía asegurar el objetivo, y por lo tanto es un caso en el que el estado de necesidad entra en juego y se cumplen sus requisitos.

\subsection{Legítima defensa}

En cuanto a la legítima defensa, existe una doctrina muy amplia que entiende que no se debe acudir a esta figura ${ }^{103}$, ya que como requisito de que exista legítima defensa se exige que provenga de una acción que ocasione una agresión ilegítima. Para empezar, un animal no puede ser sujeto de una acción, no entendida en sentido literal sino en sentido jurídico-penal, sumado a que en lo referente a la ilicitud o no de la agresión, solo pueden ser consideradas ilícitas las acciones u omisiones humanas ${ }^{104}$. Por ello no se debe considerar la legítima defensa una causa de justificación válida en este delito, debiendo acudir al estado de necesidad. Existe también un sector de la doctrina que pese a considerar la legítima defensa como no válida, presenta una excepción en la que sí lo sería, y es aquella en la que una persona utilice al animal como instrumento para perpetrar la agresión ilegítima, siendo el autor de esta agresión no el animal sino la persona que lo azuza para que ataque ${ }^{105}$.

Podemos comentar que, pese a que se intente castigar de una manera contundente el maltrato animal mediante modificaciones en el CP, la permisión que se observa en virtud de la causa de justificación "ejercicio legítimo de un derecho", conlleva que conductas escapen del tipo y queden sin castigo, dependiendo incluso en ocasiones de legisladores autonómicos en función de si permiten determinadas prácticas (como hemos visto con las peleas de gallos). De esta manera, se estaría relegando a terceras manos la punibilidad de determinadas conductas que el legislador en el momento de modificar el CP sí contemplaba como constitutivas de delito, pudiendo dejar "sin efecto" una mera ley autonómica a una Ley Orgánica como es la del Código Penal. Por ello, si de verdad se pretende acabar con todas las modalidades de maltrato existentes sin depender de ver qué se legisla posteriormente o en determinados territorios, lo más inteligente sería establecer en el propio delito un numerus clausus de situaciones en la que se excluyera la conducta del tipo en virtud de posibles causas de justificación amparadas en el ejercicio legítimo de un derecho (como la investigación científica y el consumo), siendo cualquier otra conducta típica constitutiva de delito sin atender a normas de inferior rango. ${ }^{106}$

Por último y como conclusión a este epígrafe, cabe mencionar la posibilidad de que determinadas causas de justificación que hemos visto, como por ejemplo el consumo de carne o la investigación científica, también podrían verse amparadas por una causa de atipicidad. Esta causa de atipicidad sería la de adecuación social. Bajo esta causa, una conducta que encaja en el tipo como pueden ser las mencionadas, es considerada unánimemente (o al menos mayoritariamente) como correcta, normal o cotidiana ${ }^{107}$. Mediante la normativa que hemos ido viendo en este epígrafe, la conducta está jurídicamente permitida (eso sí, como se ha analizado, estableciendo unos requisitos), y al mismo tiempo por su carácter cotidiano o normal, se puede ver amparada por esta causa de atipicidad, y es que, pese a la coincidencia formal de la conducta con los elementos objetivos del tipo, quedaría excluida la tipicidad al no haber indicio de antijuricidad ${ }^{108}$. De este modo, tendría un efecto similar al de las causas de justificación, y es que no sería punible dicha conducta.

Se podría decir que esta adecuación social existe al considerarse la conducta como normal y correcta, siempre y cuando se cumplan unos requisitos mínimos, que aunque este caso no estén regidos por ninguna ley al tratarse del concepto de lo "correcto" o "incorrecto" que tiene la sociedad y los individuos (los cuales se

103 BLANCO, I., Comentarios, IV, (Navarra, 2015) 181.

104 DÍAZ-MAROTO, J., Estudios sobre las reformas del Código Penal, 2011, 503 ss, citado por BRAGE, S., Los delitos, (Valencia, 2017) 79, nota a pie 216.

105 BRAGE, S., Los delitos, (Valencia, 2017) 79.

106 En un sentido parecido, PILAR, R., Maltrato animal, Diario ABC, 02/01/2016, Recuperado de https:/www.abc.es/natural/vivirenverde/abci-maltrato-animal-espana-queda-todavia-mucho-trabajo-hacer-materia-proteccion-

201601022021_noticia.html, consultado 15/03/2020, expone la necesidad de crear una ley marco estatal para que no dependa directamente de lo que quiera proteger o no a los animales cada Comunidad Autónoma.

${ }^{107}$ LUZÓN, D.M., Lecciones, (Valencia, 2016) 322 ss, 20/17

${ }^{108}$ Idem 
rigen por la esfera interna de éstos y no por lo que dicte ninguna ley), sin duda se acercarán ambos baremos de la adecuación social que excluye la tipicidad con los legales establecidos que permiten excluir la antijuricidad por medio de una causa de justificación como es la del ejercicio legítimo de un derecho. Considero esto ya que, lo que un principio resulta correcto y adecuado socialmente como matar a los animales en una ganadería para obtener carne, dejaría de serlo si no se cumplieran unas condiciones mínimas. Por ejemplo, si se mata a los animales haciéndoles agonizar de una manera premeditada y haciéndoles sufrir de una manera innecesaria, la conducta ya no solo dejaría de verse amparada en una causa de justificación al incumplir los requisitos o condiciones establecidos en la normativa, sino que ya tampoco se vería amparada por la causa de atipicidad de la adecuación social al no ser una conducta normal, cotidiana o correcta, pasando simplemente a ser de nuevo una conducta típica punible.

\section{Pena}

La pena prevista para el tipo básico es la de tres meses y un día a un año de privación de libertad e inhabilitación especial de un año y un día a tres años para el ejercicio de profesión, oficio o comercio que tenga relación con los animales y para la tenencia de animales.

La realidad, sin embargo, es que la pena de prisión rara vez es cumplida, ya que se acuerda la suspensión de la ejecución de la pena o su sustitución, teniendo además en cuenta que los fiscales son reacios a pedir la pena máxima contemplada, y los jueces lo son mucho más a aplicarla ${ }^{109}$.

Existe numerosa doctrina que considera que la pena privativa de libertad es totalmente insuficiente. $\mathrm{Al}$ respecto, hay autores que, por ejemplo, no entienden cómo los daños a una biblioteca, al encajar en el artículo 263.2 CP, castigado con pena de prisión de 1 a 3 años, merezcan considerablemente más pena que el maltratar a un animal aún incluso con resultado de muerte ${ }^{110}$. Otros defienden la equiparación de pena con otros ordenamientos jurídicos, donde se castiga con hasta 3 años de prisión este delito ${ }^{111}$. También se entiende que el efecto disuasorio de esta pena está totalmente en entredicho, al ni siquiera cumplirse en la mayoría de las ocasiones, y considerando que, para penar con tan poca dureza, hubiera sido casi mejor limitarse a imponer una sanción administrativa ${ }^{112}$.

Coincido con esta corriente, y es que respecto a que el número de casos de maltrato animal crezca año tras año ${ }^{113}$, se puede explicar por dos razones: la primera es que en efecto los casos reales de maltrato hayan aumentado considerablemente, lo que nos llevaría a pensar que el delito tipificado imponga una pena demasiado baja y por tanto no tenga apenas efecto disuasorio, lo que nos lleva a plantearnos seriamente si hubiera que aumentarla; la segunda explicación es que se estén denunciando más casos ahora que antes, yendo en aumento el número de denuncias (y por tanto el conocimiento de casos) pero no de casos reales de maltrato. Esto quiere decir, como se ha venido diciendo anteriormente, que existe una mayor sensibilización de la sociedad sobre el maltrato animal, percibiéndolo como más reprochable o con mayor desaprobación que la que pudiera existir hace años, entendiendo el bien jurídico protegido en este delito como algo que se deba proteger con mayor intensidad, otorgándolo más valor del que tuviera hace tiempo. Esto nos llevaría a la misma conclusión que antes, y es que, a mayor desvalor, mayores deben ser la penas. Además, si lo que aumentan son el número de denuncias y no el número de casos de maltrato reales, quiere decir que el número de casos reales siempre se ha mantenido en números muy altos (aunque lo desconociéramos), lo que nos llevaría a pensar de nuevo que el efecto disuasorio de la pena nunca ha sido realmente efectivo.

Otra corriente expresa justo lo contrario, y es que la pena de privación de libertad está bien como está, ya que al poder sustituirse fácilmente por trabajos en beneficio de la comunidad y participar en programas, entre otros, de protección animal, se evita que puedan en un futuro volver a cometer el delito ${ }^{114}$.

En cuanto a la pena de inhabilitación especial para el ejercicio de profesión, oficio o comercio que tenga relación con los animales, el juez deberá indicar expresamente la profesión de que se trate si el autor tuviera alguna profesión que en efecto trate con animales, como por ejemplo veterinario, no siendo admisible la pena en sentido amplio sobre profesiones tales como pescadero, carnicero, etc. ${ }^{115}$, que, aunque manipulan animales, ya están muertos y son dedicados exclusivamente al consumo.

\footnotetext{
${ }^{109}$ MENÉNDEZ, N., La explotación sexual de animales en Derecho Animal, 6 (2), (2015), 16, Recuperado de: https://revistes.uab.cat/da/article/view/v6-n2-menendez-de-llano/75, consultado 26/02/2020.

${ }^{110}$ MARQUÉS, M., Delitos relativos a los animales domésticos, 682, citado por BRAGE, S., Los delitos, (Valencia, 2017) 91, nota a pie 263 .

111 MENÉNDEZ, N., La explotación sexual de animales en Derecho Animal, 6 (2), (2015), 16, Recuperado de: https://revistes.uab.cat/da/article/view/v6-n2-menendez-de-llano/75, consultado 26/02/2020.

112 REQUEJO, C., La protección penal, (Granada, 2010) 57.

113 V. supra, nota a pie 17.

114 ZAPICO, M., art. 337, 453 ss, citado por BRAGE, S., Los delitos, (Valencia, 2017) 92, nota a pie 265.

115 BLANCO, I., Comentarios, IV, (Navarra, 2015) 185.

102 Derecho Animal. Forum of Animal Law Studies, vol. 12/1
} 
Por último, y en cuanto a la inhabilitación para la tenencia de animales, será efectiva desde el momento de la sentencia, sin perjuicio de que pudieran existir medidas cautelares previas, que ya hubieran despojado al autor del derecho a tener animales ${ }^{116}$. Parece una medida lógica, pues no tiene sentido que a un maltratador de animales condenado se le permita tener animales bajo su custodia, aun cuando estos animales no fueran los que han recibido el maltrato por el que se condena al autor.

Cabe preguntarse si esta inhabilitación de tener animales se extiende a la posibilidad de convivir con ellos, pues pueden existir casos, en los que, por ejemplo, un condenado viva con su pareja, la cual tenga un perro a su nombre que viva con ambos. Un sector de la doctrina entiende que, en efecto, se debería de haber extendido la pena para englobar también la convivencia con los animales, pues se podría eludir simplemente con que el animal estuviera registrado a nombre de otra persona ${ }^{117}$. Otro sector entiende que esta medida sería disfuncional, pues no garantiza el objetivo perseguido por esta pena ya que determinaría el cese de la convivencia entre el autor y la otra persona, o peor aún, que sea el animal quien tenga que abandonar la casa. De este modo, podría seguir conviviendo con animales, pero debe ser la otra persona la encargada de cuidar y ocuparse de él ${ }^{118}$. Coincido con esta última postura, añadiendo además que al interpretar extensivamente el prohibir la tenencia de animales para prohibir también la convivencia con ellos, se estaría vulnerando el principio de legalidad del Derecho Penal, ya que se estaría agravando la responsabilidad criminal al imponerle una pena más gravosa de la que se recoge en la propia ley ${ }^{119}$. Conviene añadir además que prohibir expresamente la convivencia con animales se contempló en enmiendas a la ley, aunque finalmente se desechó está fórmula ${ }^{120}$, un motivo más por el que no hay que hacer extensiva la interpretación de la tenencia de animales englobando también la convivencia.

Si bien me parecería adecuado que, en el caso de que el autor de maltrato animal tuviera que convivir con algún animal, se implantase algún tipo de medidas de control para verificar que ese animal no recibe ningún nuevo maltrato, como, por ejemplo, dar conocimiento a la Administración de las visitas periódicas al veterinario que haga la otra persona con la que convive y cuida al animal donde se exprese que el animal no presenta ningún síntoma de maltrato, abriendo diligencias si el informe veterinario no es favorable. Si bien a veces puede ser difícil comprobar la existencia de secuelas físicas si no son crónicas (pues ha podido pegar al animal y pasar la revisión veterinaria una vez se haya recuperado), para un profesional veterinario que está completamente familiarizado con el comportamiento de los animales, mediante éste puede ser en ocasiones fácilmente identificable si un animal ha sido maltratado (como por ejemplo un carácter extremadamente desconfiado y asustadizo), dando conocimiento en este caso de que existen indicios de un nuevo maltrato.

Otro problema planteado, es si el autor tuviera ya animales a su nombre antes de ser condenado. El objetivo de la pena es evitar que el autor se ocupe o cuide de ningún animal, lo que no es incompatible con que sea titular de alguno. Mientras no sea el condenado quien lo cuide, no es necesario que se traspase la titularidad $^{121}$.

\section{Tipo agravado}

“337. 2. Las penas previstas en el apartado anterior se impondrán en su mitad superior cuando concurra alguna de las circunstancias siguientes:

a) Se hubieran utilizado armas, instrumentos, objetos, medios, métodos o formas concretamente peligrosas para la vida del animal.

b) Hubiera mediado ensañamiento.

c) Se hubiera causado al animal la pérdida o la inutilidad de un sentido, órgano o miembro principal.

d) Los hechos se hubieran ejecutado en presencia de un menor de edad."

Este tipo agravado del delito se recoge en su apartado 2, donde deben estar presentes todas las

\footnotetext{
116 MENÉNDEZ, N., La explotación sexual de animales en Derecho Animal, 6 https://revistes.uab.cat/da/article/view/v6-n2-menendez-de-llano/75, consultado 26/02/2020.

${ }^{117}$ REQUEJO, C., El delito de maltrato a los animales tras la reforma del Código Penal por la Ley Orgánica 1/2015, de 30 de marzo en Derecho Animal, 6 (2), (2015), 21, Recuperado de:

https://idus.us.es/bitstream/handle/11441/86277/E1\%20delito\%20de\%20maltrato....pdf?sequence=1, consultado 26/02/2020.

118 CUERDA, M.L., Comentarios a la reforma del Código Penal de 2015, 2a , 2015, 241 ss, citado por BRAGE, S., Los delitos, (Valencia, 2017) 94, nota a pie 271.

${ }^{119}$ LUZÓN, D.M., Lecciones, (Valencia, 2016) 69, 6/11.

${ }^{120}$ REQUEJO, C., El delito de maltrato a los animales tras la reforma del Código Penal por la Ley Orgánica 1/2015, de 30 de marzo en Derecho Animal, 6 (2), (2015), 5, nota 6, Recuperado de:

https://idus.us.es/bitstream/handle/11441/86277/El\%20delito\%20de\%20maltrato....pdf?sequence=1, consultado 26/02/2020 .

121 CUERDA ARNAU, Comentarios a la reforma del Código Penal de 2015, 2a 2015, 242, citado por BRAGE, S., Los delitos, (Valencia, 2017) 94, nota a pie 273.
} 
circunstancias estudiadas para el tipo básico, así como al menos una de las circunstancias enumeradas. Se trata de circunstancias agravantes que claramente están inspiradas en el delito de lesiones a seres humanos ${ }^{122}$, debiéndose considerar en el mismo sentido que éstas ${ }^{123}$. Estas circunstancias agravarían tanto la modalidad del delito consistente en el maltrato injustificado que ocasione un grave menoscabo en la salud del animal, como en la consistente de la explotación sexual ${ }^{124}$, si bien estas circunstancias agravantes no se tienen en consideración, aun concurriendo, en el tipo cualificado por resultado de muerte (que veremos en el siguiente epígrafe), lo que resulta del todo incongruente ${ }^{125}$. En caso de concurrir alguna de las siguientes circunstancias, la pena del tipo básico se impondrá en su mitad superior, es decir, de 7 meses y medio a un año de prisión.

En cuanto a la primera circunstancia agravante, consistente en utilizar "armas, instrumentos, objetos, medios, métodos o formas concretamente peligrosas para la vida del animal", la única diferencia respecto al artículo 148.1 CP es que en éste se alude a la "salud" del lesionado, mientras que en el que estamos estudiando se alude a la "vida" del animal, lo que no tiene mucho sentido si se trata de agravar unas lesiones, lo que nos puede llevar a pensar que lo que se está castigando realmente es una tentativa de matar al animal ${ }^{126}$. Además, el sujeto activo debe ser consciente de la peligrosidad objetiva de los medios utilizados ${ }^{127}$. La jurisprudencia suele usar con frecuencia este agravante, debido a que es difícil no considerar como peligrosos para la vida los métodos o instrumentos utilizados respecto a animales que en la mayoría de casos se encuentran en situación de indefensión respecto a los humanos ${ }^{128}$.

La segunda circunstancia agravante determina que haya mediado ensañamiento. El ensañamiento en reformas anteriores del CP no figuraba como agravante específica del delito, sino que se exigía en la conducta típica, por lo que exigir que concurriera un agravante genérico contemplado ya en el artículo $22.5^{\circ} \mathrm{CP}$ para que se cumpliera el tipo denotaba una redacción muy desafortunada ${ }^{129}$. Con la reforma del 2010 se dejó de exigir que existiera ensañamiento en la conducta típica, y desde el 2015 se recoge como un agravante específico, lo que hace que los parámetros usados con los humanos y con los animales se acerquen ${ }^{130}$.

Hay que saber qué entender por "ensañamiento". Se puede definir como "la complacencia en el sufrimiento del animal en forma gratuita e innecesaria ${ }^{131 "}$ o como "hacer sufrir perversamente al animal con carácter deliberado ${ }^{132}$ ”, en el que la jurisprudencia determina que hay un elemento objetivo, entendido como la causación de unos males innecesarios, y uno subjetivo, que es ejecutarlo de manera consciente y deliberada ${ }^{133}$.

El ensañamiento es compatible tanto con la comisión por omisión como con el dolo eventual ${ }^{134}$. Así, la jurisprudencia respecto al dolo eventual establece que no es necesaria una deliberación prolongada en el tiempo, sino que basta con que el autor sepa lo que hace y que está creando un sufrimiento innecesario en la víctima, y aun así continúe con esa modalidad de ejecución. En cuanto a la comisión por omisión, señala también la jurisprudencia que, matar de hambre a un animal (comisión por omisión), es aumentar inhumanamente el dolor de la víctima. Otro ejemplo real de las muchas modalidades que puede adoptar la figura del ensañamiento, es la de aquel que ata un perro a una roca de grandes dimensiones en la playa, esperando a que suba la marea y se vaya ahogando lentamente ${ }^{135}$.

Hay autores que respecto a esta circunstancia agravante piensan que es totalmente irrelevante ${ }^{136}$, ya que

\footnotetext{
${ }^{122}$ BLANCO, I., Comentarios, IV, (Navarra, 2015) 183.

${ }^{123}$ RIOS, J.M., Comentario en relación al maltrato de animales en la nueva reforma del Código Penal español en Derecho Animal, 6 (2), (2015), 7, Recuperado de: https://revistes.uab.cat/da/article/view/v6-n2-rios/76, consultado 26/02/2020.

${ }^{124}$ BRAGE, S., Los delitos, (Valencia, 2017) 95.

${ }^{125}$ BLANCO, I., Comentarios, IV, (Navarra, 2015) 183.

${ }^{126}$ REQUEJO, C., El delito de maltrato a los animales tras la reforma del Código Penal por la Ley Orgánica 1/2015, de 30 de marzo en Derecho Animal, 6 (2), (2015), 15 ss, Recuperado de:

https://idus.us.es/bitstream/handle/11441/86277/El\%20delito\%20de\%20maltrato....pdf?sequence=1, consultado 26/02/2020.

${ }^{127}$ RIOS, J.M., Nuevos tiempos para el delito de maltrato de animales en RECPCrim, 18, (2016), 23 Recuperado de: https://pdfs.semanticscholar.org/e947/9b2c7239795a8b6b6fefb8eaccc7d5bfa931.pdf, consultado 20/03/2020.

${ }^{128}$ BRAGE, S., Los delitos, (Valencia, 2017) 96.

${ }^{129}$ RIOS, J.M., Comentario en relación al maltrato de animales en la nueva reforma del Código Penal español en Derecho Animal, 6

(2), (2015), 9, Recuperado de: https://revistes.uab.cat/da/article/view/v6-n2-rios/76, consultado 26/02/2020.

${ }^{130}$ Ibidem, 9 ss.

${ }^{131}$ RIBAS, E.R., La reforma penal de 2010: Análisis y Comentarios, 2010, 298, citado por RIOS, J.M., Comentario en relación al maltrato de animales en la nueva reforma del Código Penal español en Derecho Animal, 6 (2), (2015), 8 ss, nota a pie 19, Recuperado de: https://revistes.uab.cat/da/article/view/v6-n2-rios/76, consultado 26/02/2020.

132 REQUEJO, C., El delito de maltrato a los animales tras la reforma del Código Penal por la Ley Orgánica 1/2015, de 30 de marzo en Derecho Animal, 6 (2), (2015), 16, Recuperado de:

https://idus.us.es/bitstream/handle/11441/86277/El\%20delito\%20de\%20maltrato....pdf?sequence=1, consultado 26/02/2020.

133 Ibidem, 17

${ }^{134}$ Idem

135 RIOS, J.M., Nuevos tiempos para el delito de maltrato de animales en RECPCrim, 18, (2016), 4 Recuperado de:
} https://pdfs.semanticscholar.org/e947/9b2c7239795a8b6b6fefb8eaccc7d5bfa931.pdf, consultado 20/03/2020.

${ }^{136}$ BLANCO, I., Comentarios, IV, (Navarra, 2015) 183 ss.

104 Derecho Animal. Forum of Animal Law Studies, vol. 12/1 
de concurrir se aplicaría exactamente igual que el agravante genérico de ensañamiento, por lo que si esta circunstancia no apareciera recogida en el tipo agravado nada cambiaría.

La tercera circunstancia agravante es la de causar la pérdida o inutilidad de un sentido, órgano o miembro principal del animal. Aquí se ha de discutir qué entender por órgano o miembro principal. La fórmula defendida por algún autor es la de determinar en función del animal qué es principal y qué no ${ }^{137}$.

La jurisprudencia ha aplicado este agravante en casos de pérdida de visión de un ojo de un perro, cojera, inmovilización de patas traseras, corte de orejas o castración ${ }^{138}$. Con la entrada en vigor del Convenio Europeo sobre protección de animales de compañía, hecho en Estrasburgo el 13 de noviembre de 1987 y ratificado por España en 2017, no cabe ya ninguna duda, si es que pudiera existir, de que la amputación de cola en los perros también encajaría en este tipo agravado, pues en su artículo 10 prohíbe tanto el corte de orejas como de cola ${ }^{139}$.

Por último, la cuarta circunstancia agravante trata de los hechos que se hubieran ejecutado en presencia de un menor de edad. En esta circunstancia agravante se pone de manifiesto lo defendido en el epígrafe referido al bien jurídico protegido, y es el peso antropocéntrico que tiene éste ${ }^{140}$. De esta manera se protege a los menores porque afecta de mayor manera a sus sentimientos de amor o piedad hacia los animales y el impacto que pueda tener en su formación ${ }^{141}$. Por la misma razón que se protege a los menores de edad, llama la atención que no se haya protegido también a los discapacitados en necesidad de especial protección ${ }^{142}$.

\section{Tipo cualificado}

"3. Si se hubiera causado la muerte del animal se impondrá una pena de seis a dieciocho meses de prisión e inhabilitación especial de dos a cuatro años para el ejercicio de profesión, oficio o comercio que tenga relación con los animales y para la tenencia de animales."

Como se puede observar, que se castigue con más dureza el resultado de muerte que el de lesiones pone de manifiesto lo defendido en cuanto a la existencia de derechos subjetivos de los animales en el apartado del bien jurídico protegido.

El resultado de muerte debe ser provocado por la conducta típica exigida en el tipo básico, es decir, el maltrato injustificado ${ }^{143}$. Ello sin perjuicio y en virtud de la posición defendida en este trabajo de que la conducta típica tiene una doble vertiente: el maltrato injustificado que menoscaba gravemente la salud, y el de explotar sexualmente al animal, por lo que consideramos más que válida la aplicación de este tipo cualificado en el caso de que la conducta de explotar sexualmente al animal per se conlleve por diversos factores la muerte de éste sin que tenga que haber existido ese maltrato injustificado como tal. Por ejemplo, si tras explotar sexualmente al animal sin haberle causado ningún tipo de lesión, el animal contrajera algún tipo de infección que le acabara causando la muerte, también se podría aplicar este tipo cualificado. Realmente es un caso hipotético y excepcional, en el que prácticamente la totalidad de los casos de este tipo cualificado vendrán precedidos de la conducta típica consistente en maltratar injustificadamente al animal menoscabando gravemente su salud.

No es necesario sin embargo que exista sufrimiento en el animal, pudiéndose aplicar este tipo cualificado en casos de muerte instantánea, como por ejemplo en los casos en los que un cazador mata injustificadamente a sus galgos de un disparo en la cabeza tras haber terminado la temporada de caza ${ }^{144}$. Resultaría absurdo atendiendo al bien jurídico protegido, que este tipo de conducta quedara al margen del tipo solamente por el hecho de no haber mediado sufrimiento en el animal.

También hay que mencionar que este tipo cualificado no se puede agravar en función del $337.2 \mathrm{CP}^{145}$, por lo que, aun concurriendo una circunstancia agravante del mencionado apartado existiendo resultado de muerte, no se podrá agravar la pena de este tipo cualificado al no venir así recogido en el tipo. Sin embargo, no parece existir impedimento para poder aplicar el agravante de ensañamiento a este subtipo de resultado de muerte, no en virtud del $337.2 \mathrm{CP}$, sino al verse recogido en el artículo $22.5^{\mathrm{a}} \mathrm{CP}$ como agravante genérico.

\footnotetext{
${ }^{137}$ Ibidem, 184.

${ }^{138}$ BRAGE, S., Los delitos, (Valencia, 2017) 98.

${ }^{139}$ Lejos quedan ya las palabras de un diputado del PP, cuyo partido se opuso a la ratificación de este Convenio, en las que decía que se debía de seguir permitiendo amputar la cola de los perros para parar el "efecto látigo", mediante el cual los perros "poderosos" con su movimiento de rabo podían herir a sus cuidadores.

${ }^{140}$ RIOS, J.M., Comentario en relación al maltrato de animales en la nueva reforma del Código Penal español en Derecho Animal, 6 (2), (2015), 10, Recuperado de: https://revistes.uab.cat/da/article/view/v6-n2-rios/76, consultado 26/02/2020.

${ }^{141}$ Penal 2019, (Madrid, 2018) 1581/13987

142 BLANCO, I., Comentarios, IV, (Navarra, 2015) 183 ss.

${ }^{143}$ RIOS, J.M., Comentario en relación al maltrato de animales en la nueva reforma del Código Penal español en Derecho Animal, 6 (2), (2015), 11, Recuperado de: https://revistes.uab.cat/da/article/view/v6-n2-rios/76, consultado 26/02/2020.

${ }^{144}$ Idem

${ }^{145}$ Penal 2019, (Madrid 2018) 1581/13988
} 
Por último, debe existir una relación de causalidad entre la acción cometida y el resultado de muerte, por lo que habrá casos problemáticos en los que, por ejemplo, una enfermedad preexistente se complique a raíz del maltrato y acabe ocasionando la muerte ${ }^{146}$, o en el caso expuesto de la explotación animal para determinar si, en efecto, existe relación entre la infección mortal y la conducta llevada a cabo. Estos casos deben analizarse concretamente y con base en los criterios de imputación objetiva para determinar si es una acción adecuada para producir el resultado.

En cuanto a los grados de consumación, nada parece impedir la aplicación de tentativa en este tipo cualificado. En algún caso concreto más complejo en el que el sujeto activo, por ejemplo, disparara con animus necandi hacia un animal apuntando a la cabeza, pero fallara el disparo y diera en otra parte de éste, cabría preguntarnos si sería de aplicación la comisión en grado de tentativa del tipo cualificado, pues la intención inequívoca del autor era matar al animal, o si sería de aplicación el tipo agravado en la medida en la que se cumpla el resultado de lesiones del tipo básico y el uso de un instrumento o método peligroso para la vida del animal como puede ser el disparar con un arma de fuego. En este caso concreto, lo correcto sería aplicar un concurso ideal del tipo agravado consumado con el delito del tipo cualificado en grado de tentativa.

En otro caso en el que el sujeto activo disparara apuntando a la cabeza de un animal también con ánimo de matarle, pero fallando el disparo no dándole siquiera en ninguna otra parte del cuerpo, sí sería de aplicación directa este tipo cualificado en grado de tentativa, sin entrar con concurso con el tipo básico o agravado al no apreciarse resultado de lesiones.

\section{Tipo atenuado}

"4. Los que, fuera de los supuestos a que se refieren los apartados anteriores de este artículo, maltrataren cruelmente a los animales domésticos o a cualesquiera otros en espectáculos no autorizados legalmente, serán castigados con una pena de multa de uno a seis meses. Asimismo, el juez podrá imponer la pena de inhabilitación especial de tres meses a un año para el ejercicio de profesión, oficio o comercio que tenga relación con los animales y para la tenencia de animales."

Por su redacción, se trata de un tipo residual que trata de englobar las conductas que no se hayan podido contemplar en los tipos anteriores. Se puede decir incluso que se configura como un cajón de sastre ${ }^{147}$. Su redacción es del todo criticada por la doctrina, exigiendo en el tipo que el maltrato se realice "cruelmente", trayendo problemas antiguos como los que pudiera haber antes de la redacción del 2010, donde en el tipo básico se exigía que la conducta fuera con "ensañamiento", y teniendo en cuenta también la pobre redacción en cuanto a la delimitación del sujeto pasivo ${ }^{148}$.

En cuanto al término "cruelmente", jurisprudencia anterior a la reforma, venía definiendo este término de una manera muy similar a la que hemos visto con el término de "ensañamiento", entendido como "la complacencia en el sufrimiento o dolor del animal, en forma gratuita e innecesaria"149. Sin embargo, parece más lógico interpretarlo de una manera similar a la que se interpreta el "maltrato injustificado", pues no tendría mucho sentido exigir en el tipo atenuado un mayor contenido de injusto que en el tipo básico ${ }^{150}$. Sería incongruente por tanto exigir un mayor desvalor de la acción en el tipo atenuado que en el tipo básico o incluso cualificado.

En cuanto a la delimitación del objeto material, se determina el que "maltratare cruelmente a animales domésticos o a cualesquiera otros en espectáculos no autorizados legalmente". Debido a su redacción, existen dudas sobre si la protección a todos estos animales debe ser exclusivamente en casos de maltrato cruel en espectáculos no autorizados, o si por el contrario se protege a los animales domésticos en todo caso y a los demás solamente en espectáculos no autorizados. La doctrina mayoritaria se decanta por la segunda opción, en la que se protege a los animales domésticos en cualquier caso, y a los demás en caso de perpetrarse el maltrato en espectáculos no autorizados ${ }^{151}$. Por tanto, es de destacar también la pérdida de coherencia en

\footnotetext{
${ }^{146}$ BRAGE, S., Los delitos, (Valencia, 2017) 100.

${ }^{147}$ RIOS, J.M., Comentario en relación al maltrato de animales en la nueva reforma del Código Penal español en Derecho Animal, 6 (2), (2015), 12, Recuperado de: https://revistes.uab.cat/da/article/view/v6-n2-rios/76, consultado 26/02/2020.

${ }^{148}$ BRAGE, S., Los delitos, (Valencia, 2017) 101.

${ }^{149}$ SAP Madrid 4341/2006 de 9 de marzo.

150 HAVA, E., La protección del bienestar animal a través del Derecho penal en EPCrim, 31, (2011), 302 ss, Recuperado de: https://minerva.usc.es/xmlui/bitstream/handle/10347/7319/261-306.pdf?sequence=1\&isAllowed=y, consultado 27/02/2020.

${ }^{151}$ BLANCO, I., Comentarios, (Navarra, 2015) 187; RIOS, J.M., Comentario en relación al maltrato de animales en la nueva reforma del Código Penal español en Derecho Animal, 6 (2), (2015), 12, Recuperado de: https://revistes.uab.cat/da/article/view/v6-n2-rios/76, consultado 26/02/2020; REQUEJO, C., El delito de maltrato a los animales tras la reforma del Código Penal por la Ley Orgánica 1/2015, de 30 de marzo en Derecho Animal, 6 (2), (2015), 24, Recuperado de:
} https://idus.us.es/bitstream/handle/11441/86277/El\%20delito\%20de\%20maltrato....pdf?sequence=1, consultado 26/02/2020. 
cuanto a la delimitación del sujeto pasivo del tipo básico ${ }^{152}$. Pese al gran avance en cuanto al número de especies protegidas del tipo básico, no se aprecia esa protección en este tipo atenuado, siendo los animales domésticos unos "privilegiados" en la medida que se les protege en este tipo atenuado en cualquier situación, mientras que a las demás especies se les protege siempre que exista el pretexto de un espectáculo. De ahí viene la necesidad de lo que se defiende en el epígrafe iter criminis, que es la de admitir la comisión del tipo básico en grado de tentativa, o de lo contrario numerosas conductas reprochables quedarían fuera de la tutela penal al haber acotado de esta manera tan desafortunada los elementos normativos del tipo atenuado, como por ejemplo agredir a un animal amansado, pero sin ocasionarle un grave menoscabo a su salud.

En cuanto a los espectáculos no autorizados legalmente, no hace falta que exista ánimo de lucro en ellos ni una concurrencia determinada de personas, pero sí que carezca de autorización en cualquier caso, ya sea porque no se ha solicitado o porque se ha denegado ${ }^{153}$. Un sector de la doctrina establece que quedarían fuera del tipo los incumplimientos de los límites establecidos en la autorización ${ }^{154}$. No comparto esta posición, ya que se podría eludir la norma en numerosas ocasiones solo por el hecho de que se obtenga una autorización, siendo irrelevante si dicha autorización te permite realizar aquello en lo que vaya a consistir el espectáculo. Por ejemplo, se puede conseguir una autorización para realizar un espectáculo en el que se exhiban animales vivos, cuya autorización permite únicamente exhibirlos. En el caso de que en el espectáculo también se les someta, por ejemplo, a saltar repetidamente por aros de fuego hasta la extenuación, según esta doctrina no encajaría en el tipo al haberse conseguido autorización, aunque no se hayan respetado sus límites. Parece incongruente defender esta posición, pues el fin de la norma es precisamente proteger al animal de los tratos crueles, por lo que considero se debe interpretar de manera que la autorización no se entienda como la mera existencia de un papel, sino que se debe interpretar como la existencia de autorización para las prácticas realizadas de facto en el espectáculo. De esta manera, en el ejemplo expuesto, la conducta encajaría en el tipo atenuado, todo ello sin perjuicio de que, en función del resultado, pudiera encajar también en el tipo básico si además existen daños graves en la salud del animal, o incluso en el tipo cualificado o agravado.

En cuanto a la pena de este tipo, es de multa de uno a seis meses, con la pena potestativa de inhabilitación especial de tres meses a un año para el ejercicio de profesión, oficio o comercio que tenga relación con los animales y para la tenencia de animales.

Un ejemplo real de este tipo atenuado lo encontramos en la SAP de Barcelona 15628/2019, de 25 de noviembre, en la que el autor para que el perro del vecino parara de ladrar, le dispara con un arma de balines desde su balcón, produciéndole el balín una herida superficial en la oreja.

Particularmente considero que este tipo atenuado no aporta todo lo que podría aportar a la protección del bien jurídico, al tratarse de un supuesto tan delimitado y enfocado a espectáculos no autorizados, tipificando como elemento normativo algo que es irrelevante, y es que el maltrato se efectúe en tal espectáculo, cuando lo realmente relevante es que se realice el maltrato en sí. Al no exigir concurrencia de público, tampoco se puede entender que lo pretendido sea castigar el maltrato en caso de que se haga delante de mucha gente. Consideraría más adecuado un tipo atenuado a modo de tipo residual del tipo básico, en el que el sujeto pasivo sea el mismo que en éste, eliminando la fórmula "cruelmente" y la exigencia de que el maltrato ocurra en un espectáculo, pero diferenciándose del tipo básico en el resultado exigido, pudiéndose exigir lesiones de menor índole y por tanto pudiéndose castigar maltratos hacia los animales, pero de menor intensidad que los acaecidos en el tipo básico. Si bien acorde con lo defendido hasta el momento de la posibilidad de realizar el tipo básico en grado de tentativa (tanto acabada, realizando la conducta pero no consiguiendo el resultado de las graves lesiones exigidas, como inacabada), la existencia de este hipotético tipo se podría considerar redundante, sin embargo, sí se podría aplicar a casos en los que por los métodos de peligrosidad baja llevados a cabo o de la conducta del autor, no se pudiera deducir que pretenda ocasionar los resultados exigidos en el tipo básico, sino que, en efecto, pretenda ocasionar lesiones de menor gravedad, consumándose así el tipo atenuado.

\section{Problemas concursales}

Es posible que el $337 \mathrm{CP}$ concurra con el artículo 337 bis $\mathrm{CP}$, que no es objeto de análisis en este trabajo, en el que se castiga el abandono de animales. En ese supuesto, se aplica solamente el artículo $337.1 \mathrm{o}$ $337.3 \mathrm{CP}$, el cual absorbería al delito de abandono de animales en función del resultado conseguido, pudiéndose incluso aplicar una tentativa del artículo 337.1 o $337.3 \mathrm{CP}$ en caso de no conseguirse el resultado de lesiones o muerte en el animal ${ }^{155}$. Esto es en el caso de que las lesiones (o la muerte) se produjeran al haber

\footnotetext{
${ }^{152}$ BLANCO, I., Comentarios, IV, (Navarra, 2015) 187.

${ }^{153}$ Idem

${ }^{154}$ BRAGE, S., Los delitos, (Valencia, 2017) 106.

${ }^{155}$ Ibidem, 116.
} 
abandonado al animal, pero en el caso de maltratar a un animal y después abandonarlo, será de aplicación un concurso real de ambos delitos ${ }^{156}$.

De concurrir el artículo $337.4 \mathrm{CP}$ con el artículo 337 bis CP en caso de animales domésticos y en vistas a que tienen la misma pena ambos preceptos, se aplicaría en este caso el artículo 337 bis CP teniendo en cuenta el artículo $8.1^{\text {a }} \mathrm{CP}$, ya que se trata de un delito más especial ${ }^{157}$.

También hay tener en cuenta que, de perpetrarse el delito sobre un animal que no es de tu propiedad, entrará en concurso ideal con un delito de daños al producirse sobre el animal que es propiedad de otra persona ${ }^{158}$. De maltratar a un animal ajeno y después sustraerlo, se aplicaría un concurso real de delitos de maltrato animal y robo o hurto ${ }^{159}$, a no ser que sustraerlo haya servido como medio para poder maltratarlo o viceversa, en cuyo caso se aplicaría un concurso medial de ambos delitos.

Es de mencionar que el tipo se refiere al animal en singular y no a los animales en plural, como así ocurría antes de la reforma de 2010, por lo que, en aquel momento y a diferencia de ahora, era mucho más problemática la aplicación de concurso de delitos en caso de resultar varios animales heridos ${ }^{160}$. Así, mientras que ahora se podría aplicar un concurso real en el caso, por ejemplo, de una comisión omisiva en la que se encierre a dos animales en una casa y se les mate a ambos de hambre, antes no era posible al referirse al objeto pasivo del delito a "animales" en plural, entendiéndose englobado el herir o matar a varios animales en el mismo resultado. En este caso se aplicaría la estructura del concurso real y no la del concurso ideal al concurrir resultados homogéneos, es decir, del mismo tipo penal.

Por último, no se presentan muchas particularidades a la hora de aplicar el concurso medial de delitos. En el concurso medial, se aplicaría la pena del delito más grave en su mitad superior, como por ejemplo en el caso de que alguien irrumpa en la casa del vecino para agredir a su perro porque no para de ladrar (delito de allanamiento de morada y delito de maltrato animal).

No quería dejar pasar la oportunidad de terminar este trabajo con las palabras del gran Leonardo Da Vinci, el cual dijo: "Llegará el día en que los hombres verán el asesinato de un animal como ahora ven el de un hombre". Si bien ese día todavía no ha llegado, y es más que probable que ninguno de nosotros vea llegar ese día, sí que podemos decir orgullosos como especie que vamos encaminados a ello, siendo cada generación que pasa menos egoísta y más respetuosa con las demás formas de vida, mejorando paso a paso las condiciones de vida de las especies con la que nos toca convivir y compartir el mundo.

\section{Referencias $^{161}$}

- BeNTHAM, J., An introduction to the Principles of Morals and Legislation, 1789, recuperado de https://acortar.link/156d

- BRAGE, S., Los delitos de maltrato y abandono de animales, tirant lo blanch, (Valencia, 2017)

- ClEMENTE, L., La legitimidad de la Tauromaquia, El Mundo, 30/03/2017, recuperado de https://acortar.link/1521

- Detenido un ganadero de 26 años de Sagunto por un delito de maltrato animal de 11 bovinos y un caballo, Agroinformación, 14/09/2019, recuperado de https:/agroinformacion.com/detenido-unganadero-de-26-anos-de-sagunto-por-un-delito-de-maltrato-animal-de-11-bovinos-y-un-caballo/

- DE VICENTE, R., Vademécum de derecho penal, $5^{\mathrm{a}}$, tirant lo blanch, (Valencia, 2018)

- ELCACHO, J., Las condenas por maltrato animal se han multiplicado por 14 en la última década, La Vanguardia,

$06 / 08 / 2019$, recuperado de https://www.lavanguardia.com/natural/20190806/463897610720/estudio-seo-birdlife-denunciasdelitos-ambientales.html

- Matadero inhumano: nuevo vídeo denuncia de maltrato a corderos, vacas y caballos, La Vanguardia, 10/12/2019, recuperado de https:/www.lavanguardia.com/natural/20191210/472161697537/diainternacional-derechos-animales-video-denuncia-maltrato-matadero-albacete-equalia.html

- Excalibur ha sido sacrificado, El Mundo, 09/10/2014, recuperado de https://www.elmundo.es/espana/2014/10/08/5434f0eee2704e173e8b456f.html

\footnotetext{
${ }^{156}$ REQUEJO, C., La protección penal, (Granada, 2010) 57.

${ }^{157}$ BRAGE, S., Los delitos, (Valencia, 2017) 116 ss.

158 Penal 2019, (Madrid, 2018) 1582/13993

159 REQUEJO, C., La protección penal, (Granada, 2010) 57.

${ }^{160}$ REQUEJO, C., El delito de maltrato a los animales tras la reforma del Código Penal por la Ley Orgánica 1/2015, de 30 de marzo en Derecho Animal, 6 (2), (2015), 15, Recuperado de:

https://idus.us.es/bitstream/handle/11441/86277/E1\%20delito\%20de\%20maltrato....pdf?sequence=1, consultado 26/02/2020.

${ }^{161}$ Las palabras del título resaltadas en negrita son las que se han utilizado en las citas

108 Derecho Animal. Forum of Animal Law Studies, vol. 12/1
} 
- GARCÍA, M., El delito de maltrato a los animales. El maltrato legislativo a su protección, Revista de Bioética y Derecho, (2015), recuperado de https://www.redalyc.org/pdf/783/78343122008.pdf

- GÓMEZ, M. (dir), BLANCO, I., Comentarios prácticos al Código Penal, IV, Aranzadi, Cizur Menor (Navarra, 2015)

- GÓMEZ, M. (dir), BLANCO, I., Comentarios al Código Penal, Lex Nova, (Valladolid, 2010) recuperado de https://acortar.link/152m

- HAVA, E., La protección del bienestar animal a través del Derecho penal, EPCrim, 31, (2011) recuperado de https://acortar.link/152i

- Investigados tres ganaderos por un supuesto delito de maltrato animal, Agrodigital, 20/02/2020, recuperado de https://www.agrodigital.com/2020/02/20/360579/

- JIMENA, A., Experimentación animal: "Los científicos somos los primeros que queremos evitarla", El independiente, 04/06/2017, recuperado de https://www.elindependiente.com/futuro/2017/06/04/experimentacion-animal-los-cientificos-somoslos-primeros-que-queremos-evitarla/

- JOSA, J.M. - MAKOWSKI, M., El maltrato animal como indicador de riesgo social, Información Veterinaria, 2009, recuperado de https://acortar.link/152j

- LUZÓN, D.M., Lecciones de Derecho penal parte general, (Valencia, 2016)

- MADUEÑO, J.D., Más de la mitad quiere "limitar o prohibir" los toros y la caza, El Español, 12/01/2019, recuperado de https://www.elespanol.com/espana/20190112/mitad-quiere-limitarprohibir-toros-caza/367963207_0.html

- MENÉNDEZ, N., La explotación sexual de animales Derecho Animal, 6 (2), (2015), recuperado de https://revistes.uab.cat/da/article/view/v6-n2-menendez-de-llano/75

- MUÑOZ, J., La protección penal de los animales domésticos frente al maltrato, LLP, (2007), 42.

- Penal 2019 (Memento práctico Francis Lefebvre), (Madrid, 2018)

- PETIT, C., Fiesta y contrato. Negocios taurinos en protocolos sevillanos (1777-1847), (Madrid, 2011) recuperado de https://e-archivo.uc3m.es/handle/10016/10145\#preview

- PILAR, R., Maltrato animal: «En España queda todavía mucho trabajo por hacer en materia de protección», Diario ABC, 02/01/2016, recuperado de https://www.abc.es/natural/vivirenverde/abcimaltrato-animal-espana-queda-todavia-mucho-trabajo-hacer-materia-proteccion201601022021_noticia.html

- RIBAS, E.R., Interpretación extensiva y analogía en Derecho Penal en REDPCrim, 12, (2014), recuperado de https://acortar.link/152p

- REQUEJO, C., La protección penal de la fauna, (Granada, 2010)

- El delito de maltrato a los animales tras la reforma del Código Penal por la Ley Orgánica 1/2015, de 30 de marzo en Derecho Animal, 6 (2), (2015), recuperado de https://acortar.link/152o

- RIOS, J.M., Comentario en relación al maltrato de animales en la nueva reforma del Código Penal español en Derecho Animal, 6 (2), (2015), recuperado de https://revistes.uab.cat/da/article/view/v6-n2$\operatorname{rios} / 76$,

- Nuevos tiempos para el delito de maltrato de animales en RECPCrim, 18, (2016), recuperado de https://acortar.link/152r

- SERRA, J.M., Cerca del 60\% de los españoles se oponen a la tauromaquia, La Vanguardia, 26/01/2016, recuperado de https://acortar.link/152k

- SERRANO, M.D., El maltrato de animales en RECPCrim, 2, (2004), recuperado de http://espacio.uned.es/fez/eserv/bibliuned:revistaDerechoPenalyCriminologia-2004-extra2-

5140/Documento.pdf

- TORRES, M.E., Revisión crítica de los tipos dedicados al maltrato de animales en LLP, (2011), 78.

\section{Normativa}

\section{Normativa europea}

- Convenio Europeo de 18 de marzo de 1986 sobre protección de los animales vertebrados utilizados con fines experimentales y otros fines científicos.

- Convenio Europeo sobre protección de animales de compañía, hecho en Estrasburgo el 13 de noviembre de 1987.

- Reglamento CE 1099/2009 de 24 de septiembre de 2009 relativo a la protección de los animales en el momento de la matanza. 
- Directiva 93/119/CE, relativa a la protección de los animales en el momento de su sacrificio o matanza.

- Directiva 98/58/CE, relativa a la protección de los animales en las explotaciones ganaderas.

- Directiva 99/74/CE, por la que se establecen las normas mínimas de protección de las gallinas ponedoras.

- Directiva 2008/119/CE, relativa a las normas mínimas para la protección de terneros.

- Directiva 2008/120/CE, relativa a las normas mínimas para la protección de cerdos.

- Directiva 2010/63/CE, relativa a la protección de los animales utilizados para fines científicos.

- Directiva 98/58/CE relativa a la protección de los animales en las explotaciones ganaderas.

\section{Normativa estatal}

- Ley Orgánica 10/1995, de 23 de noviembre, del Código Penal.

- Ley Orgánica 15/2003, de 25 de noviembre, por la que se modifica la Ley Orgánica 10/1995, de 23 de noviembre, del Código Penal.

- Ley Orgánica 5/2010, de 22 de junio, por la que se modifica la Ley Orgánica 10/1995, de 23 de noviembre, del Código Penal.

- Ley Orgánica 1/2015, de 30 de marzo, por la que se modifica la Ley Orgánica 10/1995, de 23 de noviembre, del Código Penal.

- Ley 32/2007, de 7 de noviembre, para el cuidado de los animales, en su explotación, transporte, experimentación y sacrificio.

- Ley 18/2013, de 12 de noviembre, para la regulación de la Tauromaquia como patrimonio cultural, como la Ley 10/2015, de 26 de mayo, para la salvaguardia del Patrimonio Cultural Inmaterial.

- Real decreto 53/2013, de 1 de febrero, por el que se establecen las normas básicas aplicables para la protección de los animales utilizados en experimentación y otros fines científicos, incluyendo la docencia.

- Real Decreto 37/2014, de 24 de enero, por el que se regulan aspectos relativos a la protección de los animales en el momento de la matanza.

\section{Normativa autonómica}

- Ley canaria 8/1991, de 30 de abril, de protección de los animales.

- Ley andaluza 8/2003 de Flora y Fauna Silvestres.

- Ley catalana 28/2010, de 3 de agosto, de modificación del artículo 6 del texto refundido de la Ley de protección de los animales, aprobado por el Decreto legislativo 2/2008. 


\section{Anexo}

\section{Índice jurisprudencial}

- STS 3111/ 2011, de 17 de mayo.

- STS 2243/2014, de 21 de mayo.

- SAP Madrid 5431/2004, de 19 de abril.

- SAP Madrid 4341/2006, de 9 de marzo.

- SAP de Valencia 530/2010, de 1 de septiembre.

- SAP de Zaragoza 409/2015, de 10 de febrero.

- SAP de Madrid 824/2015, de 5 de octubre.

- SAP Granada 1593/2016 de 27 de septiembre.

- SAP de Las Palmas 10/2019 de 14 enero.

- SAP de Barcelona 15628/2019, de 25 de noviembre.

- Auto JPII núm. 1 de Valencia de Alcántara el 21 de junio de 2019 